
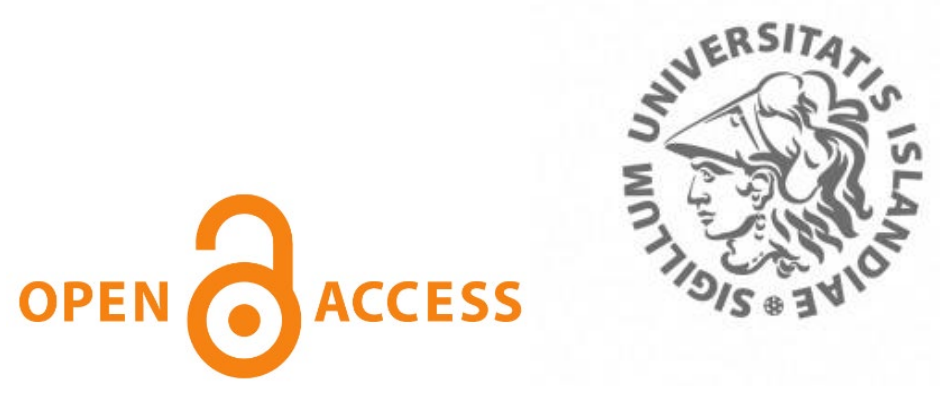

Ob Opin vísindl

This is not the published version of the article / petta er ekki útgefna útgáfa greinarinnar

Author(s)/Höf.: $\quad$ Malinauskaite, L., Cook, D., Davíðsdóttir, B., Ögmundardóttir, H., \& Roman, J.

Title/Titill: $\quad$ Willingness to pay for expansion of the whale sanctuary in Faxaflói Bay, Iceland: A contingent valuation study

Year/Útgáfuár: $\quad 2020$

Version/Útgáfa: $\quad$ Post-print (lokagerð höfundar)

Please cite the original version:

Vinsamlega vísið til útgefnu greinarinnar:

Malinauskaite, L., Cook, D., Davíðsdóttir, B., Ögmundardóttir, H., \& Roman, J. (2020). Willingness to pay for expansion of the whale sanctuary in Faxaflói Bay, Iceland: A contingent valuation study. Ocean \& Coastal Management, 183, 105026.

doi:https://doi.org/10.1016/j.ocecoaman.2019.105026

Rights/Réttur: $\quad$ C 2020 Elsevier Ltd. All rights reserved. 


\title{
Willingness to pay for expansion of the whale sanctuary in Faxaflói Bay, Iceland: a contingent valuation study
}

Laura Malinauskaite (corresponding author), Environment and Natural Resources, Faculty of Social and Human Sciences, University of Iceland, Gimli, Sæmundargata 2, 101 Reykjavík, Iceland, email: lam6@hi.is

David Cook, Environment and Natural Resources, Faculty of Environment and Life Sciences, University of Iceland, Gimli, Sæmundargata 2, 101 Reykjavík, Iceland, email: dac3@hi.is

Brynhildur Davíđsdóttir, Environment and Natural Resources, School of Engineering and Natural Sciences, University of Iceland, Oddi, Sæmundargata 2, 101 Reykjavík, Iceland, email: bdavids@hi.is.

Helga Ögmundardóttir, Faculty of Social and Human Sciences, University of Iceland, Oddi, Sæmundargata 2, 101 Reykjavík, Iceland, email: helgaog@hi.is

Joe Roman, Gund Institute for Environment, University of Vermont, Burlington, VT, email: jroman@uvm.edu

\begin{abstract}
Commercial whaling is a divisive issue in Iceland, and often considered to be irreconcilable with whale watching. The coexistence of both activities in Faxaflói Bay, adjacent to the capital city of Reykjavík, has led to the designation of part of the bay as a whale sanctuary, where whaling is banned. The study utilises the contingent valuation method to elicit the preferences of Icelanders and estimate their willingness to pay (WTP) to expand the sanctuary to the full extent of Faxaflói Bay, with an aim to inform marine spatial planning in Iceland. Using the double-bounded dichotomous approach, the mean WTP for expansion of the Faxaflói Bay Whale Sanctuary was estimated to be 5082 ISK/42 USD per person (1.32 billion ISK/10.9 million USD when multiplied by the number of taxpayers), and $29.7 \%$ of the respondents with clearly defined preferences expressed positive WTP. According to the logit regression model, statistically significant socioeconomic and attitudinal variables included age, gender, level of education, number of persons in a household, and attitudes towards environmental conservation and whaling. Policy implications of non-market valuation of marine ES are discussed, pointing to a need to further assess the multiple marine ES values applying a transdisciplinary approach to inform decision-making.
\end{abstract}

Keywords: whale sanctuary; ecosystem services; economic valuation, contingent valuation method, willingness to pay; cetaceans 


\section{Introduction}

Diverging views on the value and uses of cetaceans, the largest mammals on Earth, have been the cause of considerable controversy (Bertulli et al., 2016; Einarsson, 2009; Kalland, 1994). Commercial whaling, which has been subject to a moratorium by the International Whaling Commission (IWC) since 1986, is at the centre of this controversy, with only two members of the IWC - Iceland and Norway - still engaging in it. The departure of Japan from the IWC in 2018 demonstrates the ongoing conflict between whaling and non-whaling nations (Ackerman, 2002; Collis, 2019). The disagreement is a source of considerable tension within and outside the IWC, with strong advocacy undertaken by nation states and environmental organisations who consider whaling to be an unsustainable and inhumane practice on one side, and the support for sustainable harvesting of marine mammals as a part of the "blue growth' agenda and national identities of whaling nations on the other (Lillebø et al., 2017; NAMMCO, 2017).

The two sides of the whaling debate are particularly visible in Iceland, which left the IWC in 1992 and rejoined in 2002, after getting an exemption to the moratorium against whaling. The country resumed scientific whaling in 2003, and commercial whaling in 2006, causing an international protest (Brydon, 2006; Williams, 2006). In February 2019, the Icelandic government announced new whaling quotas for fin and minke whales for an additional fiveyear period, 2019-2023 (Vísir, 2019). The rise of tourism as the largest economicincomegenerating sector in Iceland and the subsequent expansion of the whale watching industry adds a new economic dimension to the issue, which previously had mostly been viewed from ethical (Gillespie, 1996; Scarff, 1980) and ecological (Estes et al., 2006; Roman et al., 2014) perspectives. The growing global interest in whales and income from whale watching strengthen the argument that whales may be worth more alive than dead (Einarsson, 2009). With profits from whaling declining, the opponents of commercial whaling have been using the economic argument with increased frequency (Cunningham et al., 2012; Higham et al., 2016; Lusseau, 2008; Parsons et al., 2003).

Different stakeholders' perceptions, values, and uses of whales have resulted in trade-offs between the many whale ecosystem services (ES), can be defined as the benefits that humans draw from nature (Daily, 1997). ES provided by whales they are multiple and intertwined: raw materials, recreational and aesthetic enjoyment, education, spiritual enrichment and cultural identity, and ecosystem support and regulation, among others (Cook et al., 2019a; Roman et al., 2014). Moreover, whales are considered as charismatic megafauna because of their size, appearance and perceived intelligence; they have played an important symbolic role in global conservation movement as well as the cultural identities and spirituality in numerous societies (Brydon, 2006; Kalland, 1994; Kato, 2007; Mattes, 2017). 
As whale watching emerged as an important part of many local economies worldwide (Dempster, 2009; Hoagland \& Meeks, 2000; Hoyt \& Iñíguez, 2008; O'Connor et al., 2009), the conflict between consumptive and non-consumptive uses of whales became a point of focus in conservation, tourism, international politics and ecology over the last few decades. These activities represent two potentially conflicting ways, in which humans benefit from whales, a division that is acutely apparent in Iceland (Bertulli et al., 2016; Rasmussen, 2014). The centrepiece of this controversy is Faxaflói Bay where the capital city of Reykjavík is situated and where both activities take place simultaneously in summer months, causing heightened tension between whale watching companies and animal welfare organisations on the one side and commercial whaling operators on the other (Iceland Magazine, 2017; IFAW, 2017). A whale sanctuary was created in the bay in 2007, banning whaling in the part of the bay with the most whale watching activities, with subsequent expansions in 2013 and 2017. It now encompasses around one third of the bay (Government of Iceland, 2017).

This study responds to the call for more empirical research on whaling and whale watching (Higham \& Lusseau, 2007). It attempts to inform this debate using non-market valuation, which is used to estimate willingness to pay (WTP) for changes in ES provisioning. Non-market valuation techniques have often been applied in the contexts of coastal and marine ecosystem management (Aanesen et al., 2015; Brouwer et al., 2016; Navrud et al., 2017; Shen et al., 2015; Tonin, 2018; White et al., 2012) and marine spatial planning (MSP), which is defined as 'a public process of analysing and allocating the spatial and temporal distribution of human activities in marine areas to achieve ecological, economic and social objectives that have been specified through a political process' (Ehler \& Douvere, 2009, p. 18; UNESCO, 2019). The paper presents an attempt to inform MSP in the context of whale sanctuaries by applying the contingent valuation method (CVM). It has two closely related but distinct aims: (i) to contribute to the currently limited body of academic literature on preferences and WTP related to management arrangements for marine environments and MSP; and (ii) to inform the public debate on different uses of whale ES in Iceland and their trade-offs.

\section{Case study and background}

Article $\mathrm{V}$ of the International Convention for the Regulation of Whaling (ICRW) provides the IWC with the right to adopt regulations related to management of whale stocks, including decisions about management of 'open and closed waters, including the designation of sanctuary areas' (IWC, 1946, p. 2), with a function to provide safe haven for whale populations from commercial whaling pressures. There are currently two such areas in Iceland: one in Skjálfandi Bay in the north of Iceland and another in Faxaflói Bay. Due to perceived trade-offs between commercial whaling and whale watching, a whale sanctuary was established in Faxaflói Bay in 2007, following the resumption of commercial whaling in 2006 (Althingi, 2006). 
In response to the rapid growth of the Icelandic tourism industry and subsequent expansion of whale watching activities in the bay (Fig. 1), the sanctuary was expanded in 2013 and again in 2017, from the limit between Garđskagaviti in Reykjanes peninsula to Akranes to its current limit from Garđskagaviti to Skógarnes, encompassing around one third of the total area of the bay (Fig. 2, yellow line). This was done by a change in regulation $1035 / 2017$, which forbids whale harvesting in large parts of Faxaflói and Skjálfandi Bays and affects the Icelandic Whaling Law 26/1949 (Government of Iceland, 2017).

The most recent expansion includes the vast majority of the area used for whaling, which made whaling operations less profitable as boats have to go farther out to sea. According to the figures from the Icelandic Ministry of Fisheries at the time (Fiskifréttir, 2018), 335 minke whales were caught in Faxaflói Bay from 2007 to 2016, and out of these 321 (95.82\%) were caught in the area that would be included within the expanded whale sanctuary (marked by the red line in Fig. 2). A total of 654 minke whales and 850 fin whales were hunted in Iceland from 2003 to 2018, of which 6 and 144 respectively were caught in the summer of 2018 (IoES, 2019). The harvesting levels in 2018 were well below the quota of 262 permitted for minke whales and 238 for fin whales that year. No whaling occurred in Icelandic waters in 2019. The data from the recent report on the profitability of whaling by the Institute of Economic Studies show that both minke and fin whaling in Iceland are currently not profitable (IoES, 2019). Their report also indicates that nearly all Icelandic fin whale products have been exported to Japan. Japan's withdrawal from the IWC and resumption of commercial whaling in its own waters is likely to reduce the demand for whale meat imports. A further expansion of the whale sanctuary is likely to reduce the economic viability of whaling in Iceland by increasing fuel and labour costs, as boats would have to venture farther out from the Hvalfjörður whaling station.

Whale watching in Iceland has expanded along tourism, now the largest economic sector in the country. The number of foreign visitors in Iceland grew from around 485,000 persons in 2007 to around 2.3 million in 2018 an almost five-fold increase (Icelandic Tourist Board, $2019 b)$. The number of people going whale watching in Iceland has also grown rapidly - from around 72,000 in 2003 to 345,000 in 2018 (Icelandic Tourist Board, 2019a). Multiplied by the average cost of a whale-watching tour, currently around 90 USD, the Icelandic whalewatching industry makes around 33 million USD per annum in direct income. This is a fivefold increase compared to the data from 2008 by O'Connor (2009), where direct income from whale watching in Iceland was around 6.6 million USD. The number of visitors going whale watching in Faxaflói Bay from Reykjavík also increased in tandem with the number of foreign visitors to the country-more than tenfold since the turn of the century - from around 14,000 in 2001 to 148,442 in 2018 (IceWhale, 2019) (Fig. 1). 


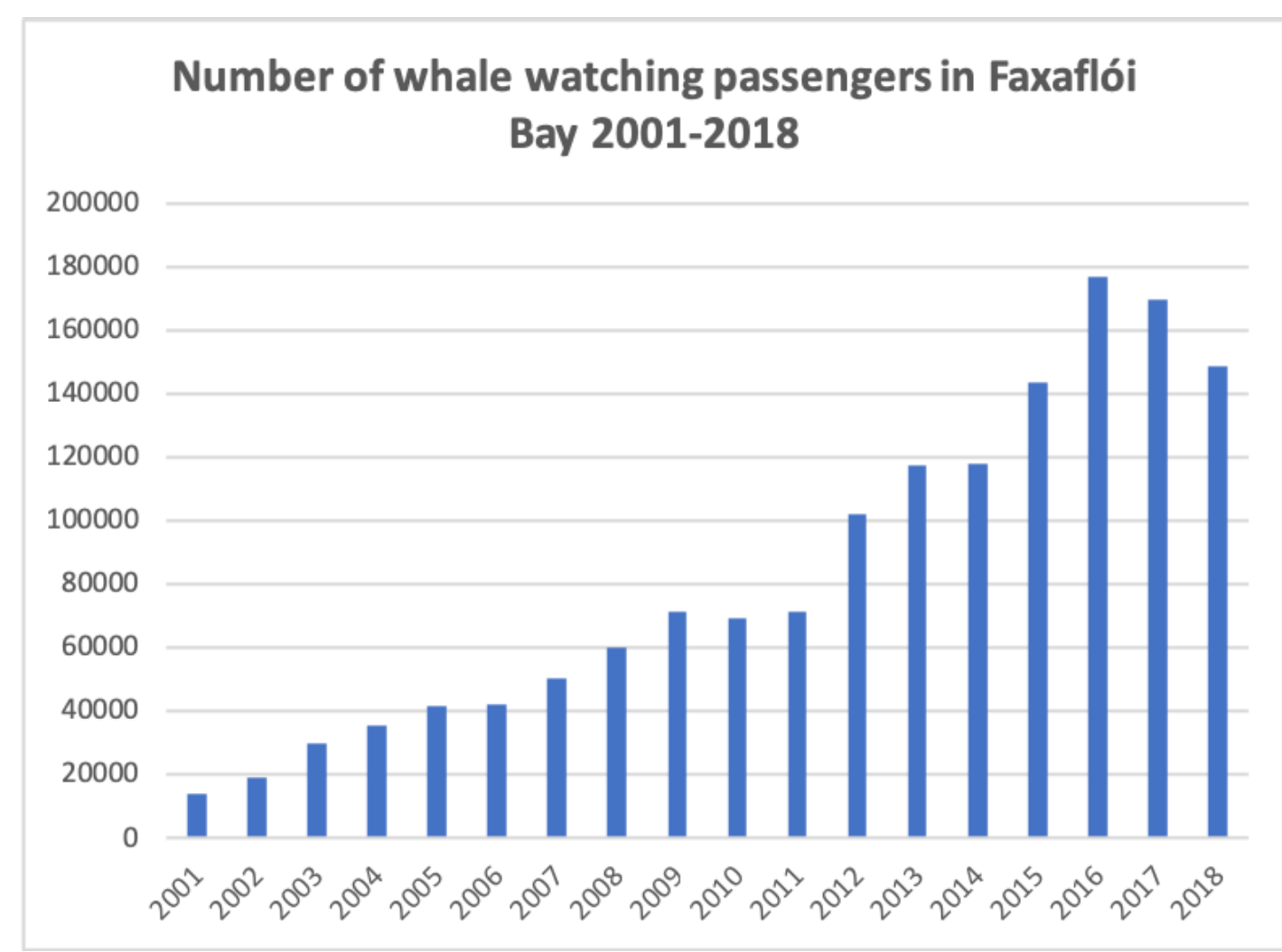

Figure 1. Number of whale watching passengers in Faxaflói Bay 2001-2018 (IceWhale, 2019).

Non-market ES valuation techniques, such as contingent valuation, have been used in the Icelandic context to elicit preferences and estimate WTP for the preservation of natural areas that are potentially subject to industrial or energy development (Cook et al., 2016, 2017; Cook et al., 2018ab; Einarsdóttir et al., 2019). There have not been any attempts to use ES valuation in the context of MSP in Iceland, yet it has been shown to improve the efficiency of marine and coastal management and provide an economic justification for conservation strategies (Börger, Beaumont, et al., 2014; Stithou \& Scarpa, 2012; Torres \& Hanley, 2017). Non-market ES valuation has been applied in MSP in various contexts, e.g. for estimating non-use values of charismatic species such as sea turtles (Jin et al., 2010; Jones et al., 2011) and marine mammals (Langford et al., 2001; Solomon et al., 2004), and informing the creation and management of MPAs (Stithou \& Scarpa, 2012; Wallmo \& Lew, 2016; Wattage et al., 2011). The relevance of non-market valuation extends to whale sanctuaries, which presents unexplored yet important topic (Dempster, 2009; Parsons et al., 2003; Rivera et al., 2007), given the heated global and domestic disputes in Iceland concerning the merits of commercial whaling.

\section{Methodology}

3.1. Economic valuation of environmental change 
The concept of ecosystem services is used by economists to estimate the contributions of ecosystems to social welfare (Braat \& de Groot, 2012; Butler \& Oluoch-Kosura, 2006; Cook et al., 2016). One of the most widely applied ES classification systems, the Common International Classification of Ecosystem Services (CICES), divides ES into provisioning, regulating and maintenance, and cultural services (Haines-Young \& Potschin, 2018). Because no markets exist for most ES, it is difficult to account for the human welfare benefits they provide in economic decision-making. Economic rationale is central to much of modern environmental policy, but because many ecosystem services have public goods characteristics and a lack of market prices, their value is at risk of being overlooked by decision-makers (Balmford et al., 2002; Barbier et al., 2009; Freeman III et al., 2014). Contingent valuation is meant to overcome this problem by creating hypothetical markets and eliciting economic values through asking people how much they would be willing to pay to obtain or avoid certain changes to the quantity and quality of supplied ES attained through changes in human activities affecting ecosystems (Freeman III et al., 2014; Pascual et al., 2010; Pearce \& Moran, 2013).

The CVM is a flexible, survey-based non-market ES valuation technique that has been in a variety of resource contexts since the 1970s (Arrow et al., 1993; Mitchell \& Carson, 2013). Perhaps to date, still the most prominent CV study in the academic literature concerns WTP to prevent another oil spill on the scale of the Exxon Valdez, which ran aground in Prince William Sound, Canada, in 1989 and remains the largest such incident in terms of the volume of oil spilt in Arctic waters (Carson et al., 1992). The study had considerable policy repercussions and affirmed the CVM as a useful valuation approach for eliciting preferences and estimating avoided damages in a marine context when market prices are not available and non-use value is prominent (Carson, 2012; Carson et al., 2003). This study applies the CVM to elicit preferences and estimate WTP in relation to a change in governance arrangements - the expansion of an existing whale sanctuary - which are assumed to imply positive environmental changes for Faxaflói Bay due to the banning of whaling.

\subsection{Survey design and administration}

The subject of this survey is the population of Iceland with the main aim to estimate Icelanders' willingness to pay for an expansion of the whale sanctuary and their attitudes towards whaling and whale watching in the country. The rationale for excluding foreign visitors from this study is that the debate between the supporters of these two activities have been very heated domestically and because Faxaflói Bay has other economic uses that are not directly related to tourism, e.g. shipping and fishing.

CV can be carried out in various ways: via postal and telephone surveys, face-to-face interviews, or a combination of these approaches (Carson \& Hanemann, 2005). With the widespread use of the internet today, web-based surveys have become very popular due to 
their cost-effectiveness and advantages related to design and implementation (Bonnichsen \& Olsen, 2016; Fleming \& Bowden, 2009; Lindhjem \& Navrud, 2011). These advantages and the fact that $96 \%$ of the Icelandic population have access to the internet (Statistics Iceland, 2017) determined the choice of the web-based survey format in this study. Furthermore, internet surveys facilitate versatile, clear and consistent presentation of information, allowing participants to revisit questions and answer them in their preferred order, omitting irrelevant questions based on previous responses. Web-based approaches are particularly useful in CV surveys when randomising bid offers in a discreet manner, leaving respondents unaware of the underlying process.

The survey was designed following the best practice recommendations made by Arrow et al. (1993), Carson (2000), Carson and Hanemann (2005), Dillman (2011) and Johnston et al. (2017). It consisted of three sections: (i) attitudinal questions on environmental issues and economic activities related to whales in Iceland; (ii) brief description of the whale sanctuary, questions on participants' familiarity with the case study site and a bidding process to elicit WTP; and (iii) a set of socio-demographic questions.

In the first section, the survey respondents were asked to pick the most and least pressing current issues in Iceland from a list of 14 environmental and socioeconomic topics dominant in the contemporary public forums in Iceland, such as press and social media. The list was finalised after consulting a mixture of recent Iceland-based CV studies and expert opinions of the authors. The rationale behind this set of questions was to examine how many people prioritise environmental issues over others and how these attitudes relate to their WTP. Next, the respondents were asked to grade on a Likert scale ${ }^{1}$ how important they consider whaling and whale watching is for the Icelandic economy, and how strongly they support or oppose minke whaling, fin whaling and whaling in general. The section ended with a question on environmental behaviour, where eight options listing examples of environmental behaviour were provided, including an open-ended option of 'other' and an option not to answer.

In the second section of the survey, a brief description and history of the Faxaflói Bay Whale Sanctuary was provided together with a map (Fig. 2), followed by questions on whether respondents had visited the area in general and in the last twelve months, how often and what activities they undertook during their visit. Those who had not visited the area were asked whether they had plans to do so. This was done to determine whether and how many of the respondents engaged in recreational activities in Faxaflói Bay and to ascertain whether frequent visits and certain activities, e.g. whale watching, sailing and fishing, influenced WTP.

After that, survey participants were asked whether they would be willing to pay a one-off lump-sum tax to expand the whale sanctuary to the proposed limit identified by the red line

\footnotetext{
${ }^{1}$ The Likert scales were presented as follows: 'completely agree/for'; 'somewhat agree/for'; 'neither nor'; 'somewhat agree/against'; and 'completely agree/against' for the two types of questions asked: 'are you for or against (different kinds of whaling)?' and 'do you agree or disagree (that whaling/whale watching is important)?'.
} 
shown in the map (Fig. 2). Then they were asked to state their reasoning, and those with WTP were asked to complete the bidding process. Following the WTP elicitation process, respondents were presented with two validity check questions to determine whether they fully understood the proposed conservation scenario (Arrow et al., 1993). The final part of the survey consisted of a standard set of sociodemographic questions to determine statistically significant characteristics affecting WTP. They were issued at the end of the survey to avoid a potential dropout of respondents as a protest, a tendency that has been recorded by Carson et al. (2001); Carson and Hanemann (2005); and Rankin and Robinson (2018).

The surveys were administered in collaboration with the University of Iceland's Social Science Research Institute, which possesses a database of over 11,000 persons representative of the Icelandic population. Prior to full dissemination, two pilot studies were sent to a small sample of 25 people each to verify the robustness of the survey design, checking for any errors or inconsistencies. Following the pilot survey and the resulting changes in the survey design, the link to the questionnaire was sent by email to 1500 randomly selected people from the database, a sample that is highly representative of the Icelandic population of 348,350 (Statistics Iceland, 2018). The online survey was open for one month from June 5 to July 5 , 2018, during the weeks prior to the resumption of minke and fin whaling in Faxaflói Bay. Respondents were sent one reminder per week over the course of the month. The number of completed surveys was 684 , amounting to a response rate of $45.6 \%$. Similar response rates were reported in other CV studies in Iceland (Cook et al., 2018b; Einarsdóttir et al., 2019), yet they are slightly lower than rates typically obtained using other survey formats, such as telephone or in-person surveys (Marta-Pedroso et al., 2007; Whitehead et al., 1993).

\subsection{Scenario description and payment vehicle}

CV surveys typically include detailed descriptions of alternative scenarios to inform respondents about environmental characteristics and economic costs of each choice, creating a hypothetical market (Carson \& Hanemann, 2005; Johnston et al., 2017). In the case of the Faxaflói Bay Whale Sanctuary, its proposed expansion was described, with regulatory and geographic information provided about the site, including the map in Figure 2. The proposed expansion would enlarge the whale sanctuary from its current limit (Fig. 2, yellow line) to the full extent of the Faxaflói Bay (Fig. 2, red line). A brief description of whaling and whale watching activities were provided along with the map to make sure that respondents were aware of the potential trade-offs and effects of the expansion on both industries. It was highlighted that around 96\% of minke whales harvested from 2007 to 2016 were caught in the area inside of the red line (Iceland Magazine, 2018), and therefore the expansion would be likely to have negative effects on whaling in the bay. 


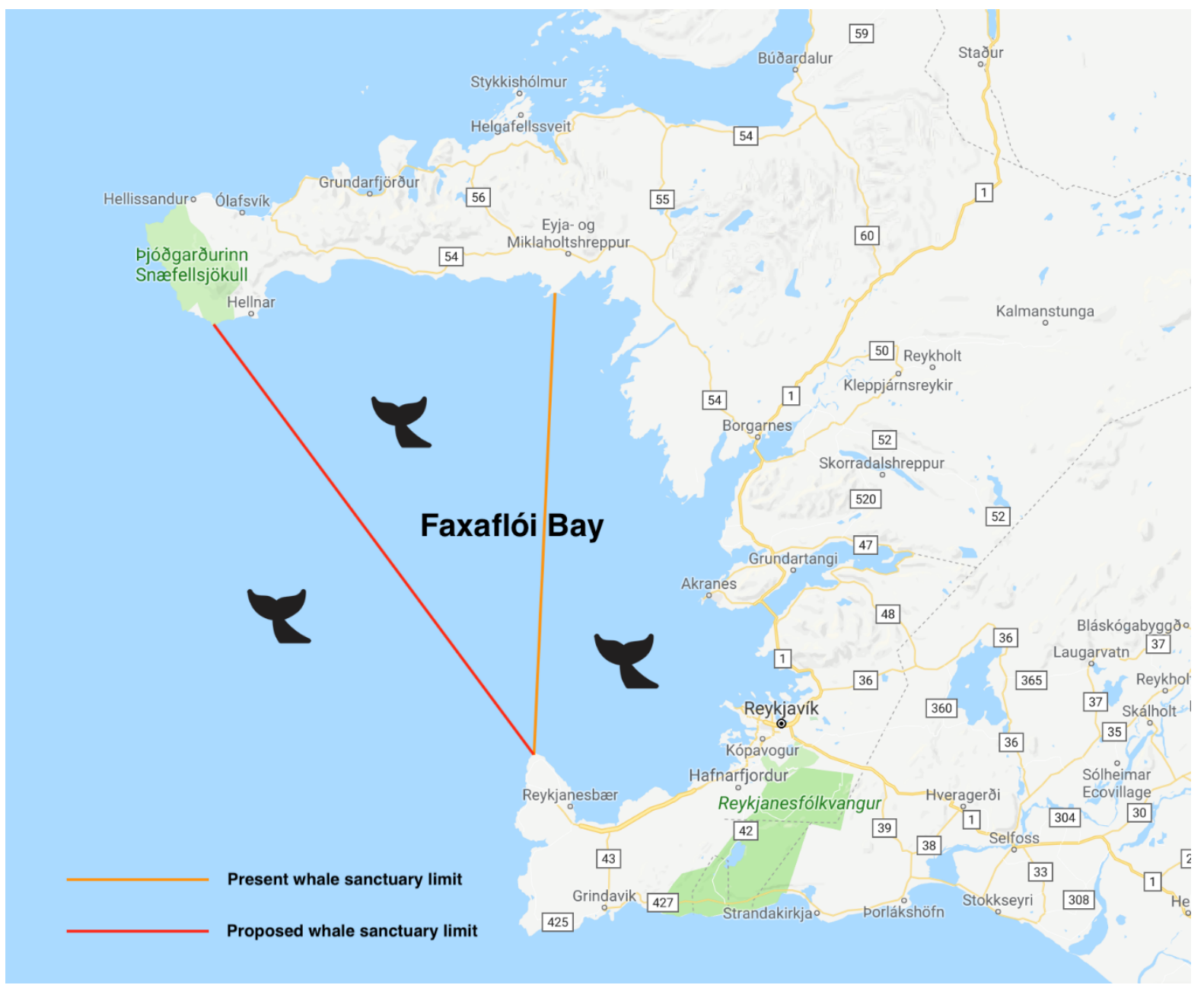

Figure 1. Current limit and proposed expansion of the Faxaflói Bay Whale Sanctuary.

Choice of payment vehicle has been found to have a significant effect on overall estimates of WTP in CV studies, therefore, it should be realistic, consequential and incentive-compatible (Mitchell \& Carson, 2013; Morrison et al., 2000). Following these recommendations, a onetime additional lump-sum tax payable by all taxpayers in Iceland over the age of 18 , irrespective of income, was chosen as the payment vehicle in this study. There were three main reasons for this choice: firstly, it is comparable to other lump-sum taxes in Iceland that respondents are likely to be familiar with, such as the annual fixed levy collected to fund the public television and radio; secondly, its technical feasibility in terms of collection that is similar to other voluntary payments; and, finally, because this type of payment vehicle was successfully deployed in other CV studies in Iceland (Cook et al., 2018a; Cook et al., 2018b; Einarsdóttir et al., 2019).

\subsection{Elicitation of willingness to pay and statistical model}

WTP elicitation methods in contingent valuation include payment cards, open-ended questions, bidding games and dichotomous choice: single, one and a half and double- 
bounded (Carson \& Hanemann, 2005; Cook et al., 2018b). The latter approach is commonly preferred by CVM practitioners due to its simplicity of use in data collection and statistical efficiency in terms of reduced coefficient variance in comparison to the other types of dichotomous choice (Arrow et al., 1993; Bateman et al., 2002; Hanemann et al., 1991), and these reasons determined the choice of the method in this case. It involves survey respondents with WTP being asked two close-ended questions with bid offers, the second bid offer being dependent on whether the first bid was accepted or not (Hanemann et al., 1991). The conditional WTP for each participant is based on the expectation that the payment amount required for expanding the sanctuary is somewhere between the lower and the upper bid of an individual. The CV literature suggests that when using double-bounded dichotomous choice, the first bid 'anchors' the second by creating a psychological perception that the 'objective' value to be estimated is close to the value of the first bid, leading to starting-point bias (Green et al., 1998; Veronesi et al., 2011). To reduce the possible influence of this bias on the overall WTP, the initial and follow-up bid amounts were randomly varied in the online survey.

Survey respondents were presented with a description of the current and alternative conservation scenarios and asked whether they would be willing to pay a one-time lump sum tax to expand the existing whale sanctuary to the full extent of Faxaflói Bay. Those who expressed WTP were presented with a randomised first bid offer of either 2,000; 4,000; 6,000; 8,000 ; or 10,000 ISK (Table 3 ). Following the approach of double-bounded dichotomous choice, if the first bid was accepted, a second, higher bid was randomly selected from the following values in ISK: 4,000; 6,000; 8,000; 10,000; 12,000; 14,000, 16,000; 18,000 or 20,000. If, on the other hand, the first bid was rejected, a randomly selected bid with one of these lower values in ISK was presented: 1,000; 3,000; 5,000; 7,000; or 9,000. The bid amounts in this study were based on recent CV studies concerned with protection of natural areas in Iceland that used the same payment vehicle (Cook et al., 2018a; Cook et al., 2018b; Einarsdóttir et al., 2019) and their appropriateness was verified by two pilot studies (each with sample of 25), in which no negative feedback was received concerning the bid amounts. On the contrary, these bid amounts were found to be realistic and plausible given the valuation scenario under their consideration.

In the statistical model, a survey respondent's WTP is presented as a linear function dependent on several variables, such as individual preferences, sociodemographic, visitor and attitudinal characteristics, and bid amounts:

$W T P_{i}=\alpha-b+x_{i}^{\prime} \beta+\mu_{\mathrm{i}}$

where $W T P_{i}$ stands for the WTP of respondent $i ; \mathrm{x}_{\mathrm{i}}^{\prime}$ is a predictor variable vector that represents an individual's socio-economic characteristics; $\alpha, b$ and $\beta$ are the parameters to be estimated; and $\mu_{\mathrm{i}}$ is an error term relating to unobserved factors. 
In the double-bounded approach, respondents are asked two rounds of questions, the second of which depends on their response to the first one. As a result, participants with WTP are divided into four groups according to their answers to the bid offers: yes/yes (yy); yes/no (yn); no/yes (ny); no/no (nn).

Following the approach of Kanninen and Khawaja (1995), the probability of a respondent saying 'yes' to the initial bid value $B I D$ is:

$P_{i}^{y}=\operatorname{prob}(y e s)=\operatorname{prob}\left(W T P_{i} \geq B I D\right)$

while the probability of a respondent rejecting the initial bid is $\left(1-P_{i}^{y}\right)$.

Following Hanemann et al. (1991), we use the logistic model where $P_{i}^{y}$ can be rewritten as:

$P_{i}^{y}=G\left(\alpha+\beta B I D_{i}\right)=\frac{1}{1+e^{-\left(\alpha+\beta B I D_{i}\right)}}$

where $G$ is the cumulative density function of the individual's $i$ maximum WTP; and $\alpha$ and $\beta$ are its vector parameters (Hanemann et al., 1991). The expression can be derived using the Hanemann (ibid.) approach where utility is a linear function of income and its error term is distributed following the extreme value of distribution. Assuming that the cumulative density function $G\left(\alpha+\beta B I D_{i}\right)$ follows logistic distribution, double-bounded dichotomous logistic models were estimated.

The latter equation (3) leads to the standard binary choice log-likelihood $L^{S B}$ function:

$L^{S B}=\sum_{i} y_{i} \log P_{i}^{y}+\sum_{i}\left(1-y_{i}\right) \log \left(1-P_{i}^{y}\right)$

where $y_{i}$ equals 1 if the response is 'yes', and 0 if otherwise.

In accordance with the approach by Hanemann et al. (1991), the probabilities of the four response possibilities following the double-bounded bid format are as follows:

$P_{i}^{y y}=\frac{1}{1+e^{-(\alpha+\beta H I G H B I D)}}$

$P_{i}^{y n}=1-\frac{1}{1+e^{-(\alpha+\beta L O W B I D)}}$

$P_{i}^{n y}=\frac{1}{1+e^{-(\alpha+\beta L O W B I D)}}-\frac{1}{1+e^{-(\alpha+\beta 1 s t B I D)}}$

$P_{i}^{n n}=\frac{1}{1+e^{-(\alpha+\beta 1 s t B I D)}}-\frac{1}{1+e^{-(\alpha+\beta L O W B I D)}}$

where $1 s t B I D$ is the value of the starting bid, $L O W B I D$ is the lower follow-up bid value, and $H I G H B I D$ stands for the higher follow-up bid value.

Given these response probabilities, the double-bounded log-likelihood $L^{D B}$ now has four parts corresponding to the four response combinations: 
$L^{D B}=\sum_{i} I_{i}^{y y} \log P_{i}^{y y}+\sum_{i} I_{i}^{y n} \log P_{i}^{y n}+\sum_{i} I_{i}^{n y} \log P_{i}^{n y}+\sum_{i} I_{i}^{n n} \log P_{i}^{n n}$

where $I_{i}$ stands for the response category for each respondent $i$.

For instances of genuine zero WTP, which excludes protest voters characterised by their objection to paying more taxes in Iceland or having other reasons for not wanting to pay the tax that did not reflect their true preferences towards expansion of the sanctuary, we applied a zero-truncated spike model (Kriström, 1997; Lim et al., 2017; Nahuelhual-Muñoz et al., 2004), which resulted in a fifth group, $I_{i}^{Z E R O}$. This approach, advised by Hanemann (1984, 1989), Haab and McConnell (1998), and Yoo and Kwak (2002), takes into account a spike at zero that constitutes the truncation of the negative part of WTP distribution and therefore allows for the inclusion of responses of genuine indifference between the two conservation scenarios by allocating them a WTP of zero (Kriström, 1997). The possibility of negative WTP was not considered in this study as per the recommendation of Hanemann (1989) and Haab and McConnell (1997) who referred to the difficulties of ad hoc distribution assumptions for negative WTP:

In the double bounded approach, the mean is calculated integrating the area under the probability function of accepting the bid. The area represents the proportion of the survey respondents who would be willing to pay each amount of the proposed tax and the utility they would get from doing so (Mamat et al., 2013). As negative WTP is not considered in this model, $W T P_{i}^{\text {mean }}$ must be greater than or equal to zero.

From the log-likelihood function (equation 3), the spike can be defined as $I_{i}^{Z E R O}=\frac{1}{1+e^{\alpha}}$ and a new cumulative distribution function can be defined as $G(\because \theta)$, where $\theta$ represents the vector of parameters $\alpha, b$ and $\beta$ presented in equation (1):

$G(W T P ; \theta)= \begin{cases}{[1+\exp (\alpha-\beta W T P)]^{1}} & \text { if } W T P>0 \\ {[1+\exp (\alpha)]^{1}} & \text { if } W T P=0 \\ 0 & \text { if } W T P<0\end{cases}$

The mean WTP in the spike model is calculated as follows (Kwak et al., 2013; Yoo \& Kwak, 2002):

$W T P_{i}^{\text {mean }}=\left(\frac{1}{\beta}\right) \log \left(1+e^{\alpha}\right)$

where $W T P_{i}^{\text {mean }}$ is mean WTP and $\alpha$ and $\beta$ are vector parameters of the cumulative density function of the individual's $i$ maximum WTP (Hanemann et al., 1991; Kwak et al., 2013).

3.5. Socio-demographic, attitudinal and visitor variable description 
Eleven socio-demographic, attitudinal and visitor variables were used in the final logistic regression model to determine statistically significant determinants of WTP2. The explanations of the variable codes are provided in Table 1.

Table 1. Predictor variables and coding.

\begin{tabular}{|c|c|}
\hline Predictor variable & Explanation of coding \\
\hline \multicolumn{2}{|c|}{ Sociodemographic variables } \\
\hline Age & Age based on participants' date of birth. \\
\hline Gender & A dummy variable, with $0=$ female and $1=$ male \\
\hline Education & $\begin{array}{l}\text { A dummy variable, with } 0=\text { no degree education and } 1=\text { at least an undergraduate } \\
\text { degree. }\end{array}$ \\
\hline Residence & $\begin{array}{l}\text { A dummy variable, with } 0=\text { residence within } 50 \mathrm{~km} \text { from the Greater Reykjavík } \\
\text { area and } 1=\text { residence outside of this boundary. }\end{array}$ \\
\hline $\begin{array}{l}\text { Participation in labour } \\
\text { market }\end{array}$ & $\begin{array}{l}\text { A dummy variable, with } 0=\text { not actively participating in the job market at the time } \\
\text { of the survey and } 1=\text { active participant. Nonparticipation includes students, the } \\
\text { retired, sick or disabled, carers, people on maternity/paternity leave and the } \\
\text { unemployed, while active participation included all employed and self-employed } \\
\text { individuals, irrespective of whether it is part-time or full time. }\end{array}$ \\
\hline Disposable income & $\begin{array}{l}\text { A dummy variable, with } 0=\text { disposable income under } 500,000 \text { ISK and } 1= \\
\text { disposable income over 500,000 ISK }\end{array}$ \\
\hline $\begin{array}{l}\text { Marital status/ } \\
\text { cohabitation }\end{array}$ & $\begin{array}{l}\text { A dummy variable, with } 0=\text { not married or cohabiting with a partner and } 1= \\
\text { married or cohabiting. }\end{array}$ \\
\hline $\begin{array}{l}\text { Number of persons in } \\
\text { household }\end{array}$ & $\begin{array}{l}\text { Coded on a scale } 0-6 \text { (with an option to state more) and represents a number of } \\
\text { persons living in the household, including the participant. }\end{array}$ \\
\hline \multicolumn{2}{|c|}{ Attitudinal and visitor variables } \\
\hline Visited Faxaflói Bay & A dummy variable, with $0=$ never having visited Faxaflói Bay and $1=$ having visited. \\
\hline Supports whaling & $\begin{array}{l}\text { A dummy variable, with } 0 \text { expressed objection to whaling in Icelandic waters and } \\
1=\text { expressed support for it. }\end{array}$ \\
\hline $\begin{array}{l}\text { Prioritises protection of } \\
\text { natural areas }\end{array}$ & $\begin{array}{l}\text { A dummy variable, with } 0=\text { did not identify 'protection of natural areas' as the } \\
\text { most important issue for the Icelandic society to solve and } 1=\text { identified it as such. }\end{array}$ \\
\hline
\end{tabular}

\footnotetext{
${ }^{2}$ Some variables were excluded from the final logistic regression to avoid using variables that were found to be correlated between themselves, e.g. number of children and number of persons in a household.
} 


\section{Results}

4.1. Responses to attitudinal questions and visiting the study area

Regarding attitudes and perceptions of the most and least important issues in the Icelandic society, improved healthcare sector and affordable housing were perceived by respondents as the most pressing, with $17.54 \%$ and $29.68 \%$ of respondents identifying them as such (Table 2). Strengthening the tourism sector was perceived as the least pressing issue $(29.09 \%)$, and protection of natural areas, which is the most relevant issue for this study, was considered the most important by $5.12 \%$ of respondents and the least by $4.39 \%$, ranking as the fifth most important and the fifth least important issue on the list.

Table 2. Most and least pressing issues for Icelandic society to address.

\begin{tabular}{|l|l|l|l|l|}
\hline \multirow{2}{*}{ Response } & \multicolumn{3}{l|}{ Most Pressing } & \multicolumn{2}{l|}{ Least Pressing } \\
\cline { 2 - 5 } & Frequency & Percentage & Frequency & Percentage \\
\hline Affordable accommodation to buy or rent & 120 & 17.54 & 10 & 1.46 \\
\hline Air pollution & 24 & 3.51 & 24 & 3.51 \\
\hline Water pollution & 7 & 1.02 & 44 & 6.43 \\
\hline Quality of education & 28 & 4.09 & 9 & 1.32 \\
\hline Social equity & 26 & 3.80 & 18 & 2.63 \\
\hline Discrimination & 49 & 7.16 & 38 & 5.56 \\
\hline Economic growth/employment & 62 & 9.06 & 17 & 2.49 \\
\hline Diversification of Icelandic economy & 19 & 2.78 & 75 & 10.96 \\
\hline Strengthening tourism sector & 7 & 1.02 & 199 & 29.09 \\
\hline Protection of natural areas & 35 & 5.12 & 30 & 4.39 \\
\hline Improving waste management & 14 & 2.05 & 17 & 2.49 \\
\hline Improving healthcare system & 203 & 29.68 & 2 & 0.29 \\
\hline Don't know & 35 & 5.12 & 43 & 6.29 \\
\hline Refuse to answer & 55 & 8.04 & 158 & 23.10 \\
\hline Total & $\mathbf{6 8 4}$ & $\mathbf{1 0 0 . 0 0}$ & $\mathbf{6 8 4}$ & $\mathbf{1 0 0 . 0 0}$ \\
\hline
\end{tabular}

In terms of environmental behaviour, the most popular ways to reduce environmental impact were recycling, saving energy and water and reducing car use. Donating to environmental causes - perhaps the most relevant environmental behaviour for this study - was an identified environmental behaviour by just over one third (34.35\%) of the respondents. About half of the respondents (47.22\%) agreed that whale watching is important for the Icelandic economy, and just over one fifth (22.22\%) agreed that the same was true for whaling. Only $5.41 \%$ strongly disagreed with the statement that whale watching was important for the Icelandic economy, while $28.46 \%$ expressed this opinion about the role of whaling. These results suggest a general consensus among respondents that, overall, whale watching plays a more significant role in the Icelandic economy than whaling. 
In terms of attitudes towards different types of whaling, $31.58 \%$ of respondents were strongly or somewhat against minke whaling, $40.79 \%$ against fin whaling, and $36.84 \%$ against whaling in general. In contrast, $39.33 \%$ were in favour of hunting minke whales, $30.41 \%$ fin whales, and $34.5 \%$ were in favour of whaling in general. In all three cases, approximately one quarter of participants (an average of $26 \%$ ) did not express an opinion, answering that they were neither for nor against it. Out of 684 persons who completed the survey, 549 (80.26\%) had visited marine and coastal areas in Faxaflói Bay, and 335 (48.98\%) did so within the twelve months prior to the time of the survey. The activities most often undertaken during visits were walking/hiking (40.64\%), sailing (22.37\%), fishing (13.45\%) and bird watching (13.89\%), and only a small fraction (6.14\%) had gone whale watching in the bay.

\subsection{Preferences and willingness to pay for the expansion of the sanctuary}

Out of the 684 respondents, 462 (67.54\%) were not willing to pay the tax, 99 (14.47\%) were willing to pay, 92 (13.45\%) were not sure, and 31 (4.53\%) refused to answer the question. All participants were asked to state their reasons for WTP or non-WTP. For the latter group, responses were analysed to determine whether they were protest voters or had genuine zero WTP. 188 (40.69\%) of the 462 respondents with no willingness to pay were deemed to be protest voters and excluded from the final results on the premise that their responses did not reflect their true preferences related to the whale sanctuary expansion, the majority of them generally not willing to pay more taxes. A further 49 participants ( $10.61 \%$ of those non-WTP) were excluded from the results as their reason for non-WTP was impossible to determine from their responses.

After these exclusions, 225 (48.70\% of the non-WTP sample and $32.89 \%$ of the whole sample) participants remained with genuine zero WTP. Zero WTP was determined either on the basis of insufficient disposable income to pay the tax or a clearly stated indifference or aversion towards the expansion of the sanctuary and was accounted for using the spike model. Reasons for non-WTP included support for whaling (56.89\%), not having sufficient income (19.11\%), and concerns over the possible expansion of whale watching activities and how that might affect the whales (14.22\%).

Out of the 99 respondents who were willing to pay, $41(41.41 \%)$ had a preference against whaling in the bay, 37 (37.37\%) believed that there are environmental benefits of expanding the sanctuary, 15 (15.15\%) expected that the expansion would increase economic benefits from whale watching, and 6 (6.06\%) believed that the expansion is needed to increase whale stocks in Icelandic waters. The reasons expressed for WTP and non-WTP complement the attitudinal data on whaling in Iceland, providing a deeper insight on respondents' reasoning in this regard. Among the 99 respondents with WTP, 92 (92.93\%) were against whaling in Iceland or indifferent, and among the 225 people with zero WTP, 148 (65.78\%) were in favour of whaling, and a further 75 (33.33\%) were either against whaling in Iceland or indifferent. 


\subsection{Bid elicitation responses}

Table 3 summarises the responses of participants to the bids offers. Among the 95 respondents who completed the bidding process, 87 (87.88\%) accepted the first bid offer and $12(12.63 \%)$ rejected it. Subsequently, of the 87 participants who accepted the first bid offer, 45 (51.72\%) answered 'yes/yes', 38 (43.68\%) answered 'yes/no', and 4 (4.60\%) refused to answer, resulting in their responses being dropped from the final results. From the 12 respondents who rejected the first bid offer, 8 (66.67\%) had 'no/yes' and 4 (33.33\%) had 'no/no' responses. The acceptance probability of the first bid gradually decreased as the sums increased, except for 6.000 ISK bid, but it is more random in the second bid where the highest bid acceptance rates are for 14.000 ISK and 8.000 ISK (not including 4.000 ISK, which was only offered once). Similar bid acceptance patterns were found in other ES valuation studies focused on marine and coastal protection (Rodella et al., 2019; Wang \& Jia, 2012).

Table 3. Summary of bid responses.

\begin{tabular}{|c|c|c|c|c|c|c|c|c|c|}
\hline $\begin{array}{c}\text { First bid } \\
\text { amount } \\
\text { ISK }\end{array}$ & Yes & No & $\begin{array}{l}\text { Second } \\
\text { higher } \\
\text { bid } \\
\text { amount } \\
\text { ISK }\end{array}$ & Yes & No & $\begin{array}{c}\text { Refuse to } \\
\text { answer }\end{array}$ & $\begin{array}{c}\text { Second } \\
\text { lower bid } \\
\text { amount } \\
\text { ISK }\end{array}$ & Yes & No \\
\hline 2000 & $\begin{array}{l}17 \\
(94.44 \%)\end{array}$ & $1(5.56 \%)$ & 4000 & $\begin{array}{l}1 \\
(50.00 \%)\end{array}$ & $\begin{array}{l}1 \\
(50.00 \%)\end{array}$ & 0 & 1000 & $\begin{array}{l}2 \\
(66.66 \%)\end{array}$ & $\begin{array}{l}1 \\
(33.33 \%)\end{array}$ \\
\hline 4000 & $\begin{array}{l}17 \\
(89.47 \%)\end{array}$ & $\begin{array}{l}2 \\
(10.53 \%)\end{array}$ & 6000 & $1(100 \%)$ & 0 (0.00\%) & 0 & 3000 & $\begin{array}{l}5 \\
(71.43 \%)\end{array}$ & $\begin{array}{l}2 \\
(28.57 \%)\end{array}$ \\
\hline 6000 & $\begin{array}{l}18 \\
(94.74)\end{array}$ & $1(5.26 \%)$ & 8000 & $\begin{array}{l}4 \\
(50.00 \%)\end{array}$ & $\begin{array}{l}4 \\
(50.00 \%)\end{array}$ & 0 & 5000 & $\begin{array}{l}1 \\
(100.00 \%)\end{array}$ & 0 \\
\hline 8000 & $\begin{array}{l}14 \\
(82.35 \%) \\
\end{array}$ & \begin{tabular}{|l|}
3 \\
$(17.65 \%)$ \\
\end{tabular} & 10000 & $\begin{array}{l}5 \\
(62.50 \%) \\
\end{array}$ & $\begin{array}{l}3 \\
(37.50 \%) \\
\end{array}$ & 0 & 7000 & 0 & 0 \\
\hline \multirow[t]{5}{*}{10000} & $\begin{array}{l}21 \\
(80.77 \%)\end{array}$ & $\begin{array}{l}5 \\
(19.23 \%)\end{array}$ & 12000 & $\begin{array}{l}7 \\
(46.67 \%)\end{array}$ & $\begin{array}{l}6 \\
(40.00 \%)\end{array}$ & $\begin{array}{l}2 \\
(13.33 \%)\end{array}$ & 9000 & 0 & $\begin{array}{l}1 \\
(100.00 \%)\end{array}$ \\
\hline & & & 14000 & $\begin{array}{l}9 \\
(75.00 \%)\end{array}$ & $\begin{array}{l}3 \\
(25.00 \%)\end{array}$ & 0 & & & \\
\hline & & & 16000 & $\begin{array}{l}6 \\
(42.86 \%)\end{array}$ & $\begin{array}{l}7 \\
(50.00 \%)\end{array}$ & 1 (7.14\%) & & & \\
\hline & & & 18000 & $\begin{array}{l}4 \\
(44.44 \%)\end{array}$ & $5(55.56)$ & 0 & & & \\
\hline & & & 20000 & $\begin{array}{l}8 \\
(44.44 \%)\end{array}$ & $\begin{array}{l}9 \\
(50.00 \%)\end{array}$ & $1(5.56 \%)$ & & & \\
\hline $\begin{array}{l}\text { Total (\% } \\
\text { of } 99)\end{array}$ & $\begin{array}{l}87 \\
(87.88 \%)\end{array}$ & \begin{tabular}{|l}
12 \\
$(12.12 \%)$
\end{tabular} & $\begin{array}{l}\text { Total }(\% \\
\text { of } 87)\end{array}$ & $\begin{array}{l}45 \\
(51.72 \%)\end{array}$ & $\begin{array}{l}38 \\
(43.68 \%)\end{array}$ & $4(4.60 \%)$ & $\begin{array}{l}\text { Total (\% } \\
\text { of } 12)\end{array}$ & $\begin{array}{l}8 \\
(66.67 \%)\end{array}$ & $\begin{array}{l}4 \\
(33.33 \%)\end{array}$ \\
\hline
\end{tabular}

4.4. Socio-demographic characteristics 
Table 4 provides the descriptive statistics for the regression model's predictor variables grouped according to respondents' WTP (positive or zero) for the expansion of the sanctuary. The mean outcomes with standard deviations in parentheses are provided for each predictor variable. The predictor variable information suggests that those willing to pay for the expansion tend to be slightly younger with an average age of around 47 as opposed to 52 for those with zero WTP; better educated, with 52\% and 32\% respectively being degreeeducated; and tend to prioritise protection of natural areas more than the respondents with zero WTP. Gender and support for whaling were other two variables that differed considerably between the groups, with $60.61 \%$ of those with WTP being female compared to $39.39 \%$ of those with no WTP. Far fewer whaling supporters were willing to pay for the sanctuary expansion (7.07\%), compared to $65.78 \%$ whaling supporters that had genuine zero WTP.

Table 4. Summary of predictor variables.

\begin{tabular}{|c|c|c|}
\hline Predictor variables & WTP for expansion $(n=99)$ & Genuine zero WTP $(n=225)$ \\
\hline & Mean (Standard Deviation) & Mean (Standard Deviation) \\
\hline \multicolumn{3}{|l|}{ Sociodemographic variables } \\
\hline Age & $46.66(19.21)$ & $52.47(15.85)$ \\
\hline Gender & $0.39(0.49)$ & $0.66(0.47)$ \\
\hline Education & $0.52(0.50)$ & $0.32(0.47)$ \\
\hline Residence & $0.74(0.44)$ & $0.67(0.47)$ \\
\hline Participation in labour market & $0.66(0.48)$ & $0.72(0.45)$ \\
\hline Disposable income & $0.15(0.36)$ & $0.23(0.42)$ \\
\hline Marital status/ cohabitation & $0.67(0.47)$ & $0.78(0.41)$ \\
\hline Number of persons in household & $2.63(1.34)$ & $2.95(1.41)$ \\
\hline \multicolumn{3}{|l|}{ Attitudinal and visitor variables } \\
\hline Visited Faxaflói Bay & $0.67(0.47)$ & $0.63(0.48)$ \\
\hline Supports whaling & $0.07(0.26)$ & $0.66(0.47)$ \\
\hline Prioritises protection of natural areas & $0.20(0.40)$ & $0.02(0.14)$ \\
\hline
\end{tabular}

\subsection{Logistic regression model and WTP estimates}

The results of the logistic regression model with standard errors in parentheses are presented in Table 5. As a result of the failure by some respondents to complete either the attitudinal or the socio-demographic survey questions, the eventual sample dropped from 324 to 287 observations. In the logistic regression, the most important determinant of WTP is the constant and the statistically significant predictor variables include age, number of persons in the household, support for whaling and prioritising protection of protected areas, which were all significant at the $1 \%$ level. Education was significant at the $5 \%$ level; and gender - at the $10 \%$ level.

Table 5. Logistic regression results - Faxaflói Bay.

\begin{tabular}{|l|l|}
\hline Variable & Coefficient (Standard Error) \\
\hline
\end{tabular}




\begin{tabular}{|c|c|}
\hline \multicolumn{2}{|l|}{ Socio-demographic } \\
\hline Age & $-0.312(0.118)^{* * *}$ \\
\hline Gender & $-0.595(0.346)^{*}$ \\
\hline Residence & $0.115(0.388)$ \\
\hline Education & $0.715(0.360)^{* *}$ \\
\hline Labour market participation & $-0.203(0.412)$ \\
\hline Income over 500,000 ISK & $-0.286(0.464)$ \\
\hline Marital/cohabitation status & $0.492(0.422)$ \\
\hline Number of persons in the household & $-0.430(0.146)^{* * *}$ \\
\hline \multicolumn{2}{|l|}{ Attitudinal and visitor } \\
\hline Visited Faxaflói Bay & $0.549(0.497)$ \\
\hline Supports whaling & $-2.917(0.444)^{* * *}$ \\
\hline Prioritises protection of natural areas & $1.957(0.660)^{* * *}$ \\
\hline Constant & $2.155(0.895)^{* * *}$ \\
\hline $\mathrm{N}$ & 287 \\
\hline Log-likelihood & -115.245 \\
\hline $\mathrm{LR} \mathrm{Chi}^{2}$ & 139.320 \\
\hline Prob. $>\mathrm{Chi}^{2}$ & 0.000 \\
\hline Pseudo R2 & 0.377 \\
\hline
\end{tabular}

***indicates significance at $1 \%$ level; ${ }^{* *}$ significance at $5 \%$ level, and ${ }^{*}$ at $10 \%$ level.

The mean WTP calculated using logistic regression and the zero-spike model is set out in Table 6. When the 225 observations with zero WTP were included, the mean WTP was 5,082 ISK (42 USD in 2018 prices); if we restricted the observations to non-zero WTP, the mean was 17,117 ISK (141 USD in 2018 prices). When the mean WTP (including genuine zeros), is multiplied by the number of tax payers in Iceland in 2016, which was around 260,426 (Directorate of Internal Revenue, 2016), it amounts to around 1.32 billion ISK (10.9 million USD in 2018) (Table 6).

Table 6. Mean willingness to pay for expansion.

\begin{tabular}{|c|c|c|c|c|c|c|}
\hline Variable & $\begin{array}{l}\text { Number of } \\
\text { observations }\end{array}$ & Mean ISK & $\begin{array}{l}\text { Standard } \\
\text { error }\end{array}$ & $\begin{array}{l}95 \% \text { confi } \\
\text { interval }\end{array}$ & ence & $\begin{array}{l}\text { Multiplied by } \\
\text { Icelandic taxpayers }\end{array}$ \\
\hline $\begin{array}{l}\text { WTP (including } \\
\text { genuine zero } \\
\text { WTP) }\end{array}$ & 320 & 5082 & 553.1174 & 3993.431 & 3993.431 & $\approx 1.32$ billion ISK \\
\hline $\begin{array}{l}\text { WTP (excluding } \\
\text { genuine zero } \\
\text { WTP) }\end{array}$ & 95 & 17117 & 1142.628 & 14848.42 & 14848.42 & $\approx 4.46$ billion ISK \\
\hline
\end{tabular}

\section{Discussion}




\subsection{Attitudinal data}

The problems in the healthcare sector and lack of affordable housing that have dominated the Icelandic public debate over the last few years were most often marked in the survey as the most pressing issues. That just over $5 \%$ of respondents chose the protection of natural areas as the most pressing issue in Iceland indicates limited concern about nature conservation, which may be partly due to the perceived pristineness of Icelandic nature, a commonly reported preconception (Karlsdóttir, 2013; Sæpórsdóttir et al., 2011; Sæpórsdóttir et al., 2018). Recycling and improving efficiency of resource use were most often selected types of individual environmental behaviour, which is similar in other OECD countries (Eurobarometer, 2014).

The respondents' scepticism about the importance of whaling to the Icelandic economy resonates with the ongoing debate on the economic viability of whaling, where the majority of opinions in the popular media argue that whaling is a loss-making industry that damages the image of Iceland internationally (Kjarninn, 2015), while their opposition contends that controlled harvesting of whales is a sustainable use of natural resources (IoES, 2019) and a part of Icelandic national identity (Brydon, 2006).

The survey results reveal an approximately three-way division of opinion about Icelandic whaling - one third for, one third against and one third indifferent. This division largely coincides with the recent survey data from Gallup (2017) and Media and Market Research Iceland (MMR, 2018). In 2017, 24.7\% of surveyed Icelanders were against minke whaling, $45.8 \%$ were in favour of it, and $29.5 \%$ did not express an opinion. The respective percentages for fin whaling were $29.3 \%$ against, $35.4 \%$ for, and $35.4 \%$ neutral. MMR survey data from 2018 shows that $34 \%$ were supportive of a resumption of whaling in Iceland in $2018,34 \%$ were against, and $31 \%$ did not express an opinion.

The relatively lower support for fin whaling can perhaps be explained by the fact that fin whales are an endangered species globally according to the International Union for Conservation of Nature (IUCN) and that its harvesting in Iceland has been unsteady and resumed in 2018 after a two-year break (IoES, 2019). Even though fin whale stocks in Iceland are reportedly healthy and the harvesting quota adheres to strict standards (Víkingsson, 2019), the endangered status makes their utilisation less appealing to the public. Moreover, resumption of fin whaling has received a considerable amount of attention in the international media (The Guardian, 2018; The Seattle Times, 2018), which may have influenced respondents' opinions, together with the fact that fin whales are much larger animals than minke whales that have been more commonly hunted in Icelandic waters.

\subsection{Willingness to pay outcome}


WTP elicited in this study of 5082 ISK/42 USD per person is considerably lower than the individual WTP estimates from the previous CV studies in Iceland, which range between 7,122 ISK/60 USD and 24,790 ISK/207 USD (2018 prices) (Cook et al., 2018a; Cook et al., 2018b; Einarsdóttir et al., 2019). This may be partly due to the differing contexts - the previous CV studies in Iceland were concerned with preservation of currently unprotected natural sites while this case is related to expansion of an existing protected area. Moreover, this is the first $\mathrm{CV}$ study in Iceland concerning non-market valuation of marine environments while the earlier studies focused on terrestrial ecosystems. The former have been widely debated and have been on the public policy agenda or a few decades while the latter dates back just over a decade since the resumption of commercial whaling.

One of the reasons provided by respondents for non-WTP was the fact that expanding the sanctuary in does not imply any major transaction costs as it involves simply redrawing, 'an imaginary line in the water' (survey data). Moreover, $14.22 \%$ of those with genuine zero WTP expressed their concern over potential negative effects of expanding whale watching activities in the bay. This concern is legitimate as whale sanctuaries by default do not imply any control over activities other than whaling, while whale watching presents its own disturbances to whales (Cook et al., 2019b; Lusseau \& Bejder, 2007; Ritter, 2003).

Even if lower compared to the previous ES valuation studies in Iceland, the WTP sum of 1.32 billion ISK elicited in this study is not insignificant when put into the context of the economic gains from whale ES through commercial whaling and whale watching. The most recent data from the Institute of Economic Studies at the University of Iceland (IOES, 2019) estimates that minke whaling made around a 3.8 million ISK (32,000 USD) loss in 2016, and fin whaling was not economically viable during the first few years after its resumption in 2013 due to high initial costs of restarting operations. The total income from whale watching in Iceland, according to the same study, was 3.2 billion ISK (27 million USD) in 2017, with total profits of around 100 million ISK $(855,000$ USD) (IoES, 2019, p. 21). The WTP to expand the sanctuary elicited in this study amounts to around $41 \%$ of the total income from whale watching in 2017. When the number of whale watching passengers in the Faxaflói Bay in the same year $(169,630$ according to IceWhale (2019), is multiplied by the average cost of a whale watching tour from the Reykjavík harbour (around 11,000 ISK), the direct expenditure amounts to around 1.9 billion ISK (16 million USD), of which the aggregate WTP in this study is around 68\%.

The fact that respondents with positive WTP were willing to pay significantly more than the whole sample including zero WTP highlights that the issue of whaling in Iceland provokes strong diverging opinions, either for or against, and reiterates the main points of the discussion on participants' attitudes in relation to opinion polls on public support for whaling in Iceland (Gallup Iceland, 2017; MMR, 2018). The proportion of the sample (after exclusion of protest voters) who were willing to pay for the expansion was almost $30 \%$, which is similar to the proportion of the Icelandic population that expressed their aversion to whaling in the previous polls. 
This study contributes to the growing body of literature concerned with non-market valuation of marine ES and MPAs, yet varying contexts and approaches to study design limit the comparability of WTP outcomes. A few recent studies broadly related to the underlying general themes of this paper and applying similar valuation methods include Casiwan-Launio et al. (2011) on residents' WTP and willingness to work (WTW) for the preservation of a fishery reserve in Philippines Bicol region; Boxall et al. (2012) on the economic values associated with the recovery of marine mammal populations in Canada; Kenter et al. (2013) CV study on divers' and anglers' WTP for potential MPAs in the UK; and Batel et al. (2014) on economic values of marine conservation of an MPA for bottlenose dolphins. The study also resonates with some of the broader themes in literature on the role of ES valuation in MPA management and marine spatial planning (Hanley et al., 2015; Hussain et al., 2010; Jobstvogt, Hanley, et al., 2014; Russi et al., 2016; Torres \& Hanley, 2017).

\subsection{Significance of the sociodemographic characteristics for WTP}

The statistical significance of age and gender for WTP in the regression model coincides with frequent association of support for whaling in Iceland with statistically older male population. There was no significant correlation between WTP and income but the number of persons in the household was significant at $1 \%$ level. This suggests that disposable income does not have a significant association with WTP but having to support more family members does. Jacobsen and Hanley (2009) in an analysis of 46 contingent valuation studies concerned with biodiversity preservation from around the world found that income was only significant in $39 \%$ of the database studies. Non-significance of income for WTP is also prevalent in a number of non-market valuation studies concerned with marine conservation (Batel et al., 2014; Börger, Hattam, et al., 2014; Robles-Zavala \& Chang Reynoso, 2018), but has been found to be significant in others (Brouwer et al., 2016; Jobstvogt, Watson, et al., 2014; Ressurreição et al., 2011; Ressurreição et al., 2012).

Gender, age and education have been found to have significant correlation with WTP in numerous ES valuation studies in industrialised countries (Jin et al., 2010; Liu et al., 2019; Ressurreição et al., 2011). Comparing the logistic regression model results to other CV studies in Iceland, gender, education, residence and high income were also found to be statistically significant in the CV studies of Hverahlíð and Eldvörp geothermal areas (Cook et al., 2018a). Income also had a statistically significant impact on WTP for preservation of the Heiðmörk natural park near Reykjavík (Cook et al., 2018b).

\subsection{Implications of the study outcomes for decision-making}

Marine and coastal ES specification, valuation and analysis of trade-offs have the potential to inform decision-making and maximise ecological, economic and social outcomes pertaining 
to their management (Brown et al., 2001; Lester et al., 2013; White et al., 2012). The aggregate WTP of 1.32 billion ISK elicited in this study could be used to communicate Icelanders' preferences related to expansion of the Faxaflói whale sanctuary, e.g. included in a cost-benefit analysis (CBA), should one be undertaken. Since the expansion would simply entail moving the sanctuary limit, the costs are likely to be negligible and the CBA would be likely to pass the Samuelson (1954) test, meaning that the aggregate social benefits would exceed the costs and characterise the change as socially desirable (Rodella et al., 2019). Moreover, the WTP estimate, together with the attitudinal data, could be used to support arguments concerning the significance of cultural ES provided by whales and to depict Icelandic stakeholder views on economic activities taking place in Faxaflói Bay when making decisions related to marine spatial planning.

Whale sanctuaries, however, are a rather weak form of environmental governance with the only activity prohibited in them being commercial whaling while other activities with potential impacts on whales, such as sailing, whale watching, fishing and shipping, remain unaffected (Gjerden, 2008; Hinch \& De Santo, 2011; Hoyt, 2005, 2012). Reviews of the two large IWCdesignated whale sanctuaries conclude that they lack scientific basis for the efficient protection of species and have been politically rather than scientifically motivated (Gerber et al., 2005; Zacharias et al., 2006). Cook et al. (2019b) find that the contribution of the Faxaflói Bay Whale Sanctuary to ecosystem-based management is very limited and that a clear set of preferences and measurable objectives is necessary to improve its efficacy. With an increasing number of economic activities taking place in the bay, there is a need for marine spatial planning that considers risks, interactions and trade-offs between them, and economic ES valuation can play an important role in decision-making.

\subsection{Ecosystem services implications of study}

Our study indicates that there may be a change in the ES provided by whales in Faxaflói Bay if the whale sanctuary was expanded: more cultural ES sourced through whale watching and reduced provisioning ES from whaling. The most recent expansion of the sanctuary in 2017 already caused a considerable decline in minke whaling (Fiskifréttir, 2018). The proposed expansion is likely to make whaling even less profitable as vessels would have to venture farther away from the whaling station, thus reducing the supply of provisioning ES sourced from whales. On the other hand, the proposed expansion is likely to have a positive impact on whale watching and the supply of cultural whale ES. The previous increase in the size of the sanctuary was at least partly motivated by potential benefits to tourism (Vísir, 2017). That $47.22 \%$ of respondents identified whale watching as important for the Icelandic economy compared to $28.46 \%$ who thought that whaling is important suggests that the economic gains from cultural ES are perceived to be more significant than those from provisioning ES. Whale watching activities, however, can have their own effects on whales, raising environmental concerns (Lusseau \& Bejder, 2007; Rasmussen, 2014; Ritter, 2003). A study by Christiansen \& 
Lusseau (2015) focused on Faxaflói Bay revealed that encounters with whale watching boats cause behavioural disturbances in minke whales, leading to changes in feeding and breeding habits, and that a large increase in these interactions could negatively affect long-term whale conservation in the bay.

\subsection{Study limitations and further research}

In the absence of other attempts to assess values of whale ES in Iceland, this study serves as a guide for further research on the topic, yet it is not without its limitations. Firstly, to address the management needs, other ES value dimensions than monetary should be studied (Martinez-Alier et al., 2010; Stålhammar \& Pedersen, 2017). For example, non-WTP for the sanctuary expansion does not necessarily imply that people do not value certain whale ES they may value them in non-monetary terms, e.g. intrinsic values concerning existence, inspiration or aesthetic enjoyment (Chan et al., 2012; Jacobs et al., 2016; Kato, 2007). These values can be accounted for using non-monetary ES valuation techniques, e.g. sociocultural valuation, and integrated valuation methods (Dempster, 2009; Gómez-Baggethun \& MartínLópez, 2015; Gómez-Baggethun et al., 2014).

Secondly, due to the lack of reliable scientific information, descriptions of the conservation scenarios did not include predicted changes in whale ES and respondents had to make decisions based on incomplete information, which can potentially reduce the reliability of the study (Blomquist \& Whitehead, 1998; Schläpfer, 2008). The current scientific knowledge about biophysical processes in the Faxaflói Bay marine ecosystem in relation to different economic activities and ES provisioning is very limited, therefore natural science research in these areas would be instrumental in enabling better-informed future valuation studies (Guerry et al., 2012; Tallis \& Polasky, 2009).

Thirdly, a relatively high proportion of protest voters presents a potential problem to the reliability of WTP results. The $41 \%$ proportion of protest voters determined in this study reaches the upper limit of the acceptable range of between $20 \%$ and $40 \%$, as defined by Carson (1991). However, the proportions of protest voters vary greatly between other CV studies in Iceland - from $24 \%$ to $81 \%$ - which can be explained by the perception of already high taxes and the tendency of the public to distrust government spending (Cook et al., 2018a; Cook et al., 2018b; Einarsdóttir et al., 2019). In CV studies concerned with marine conservation from other parts of the world, the percentage of reported protest voters ranges from 10\% (Ressurreição et al., 2011) to 20\% - 42\% (Giraud et al., 2002; Jobstvogt, Watson, et al., 2014; Rodella et al., 2019; Wang \& Jia, 2012).

Protest voters were excluded from the final results of the study following recommendations by Edwards and Anderson (1987), Jorgensen et al. (1999) and Carson and Hanemann (2005) in order to avoid distortion of WTP results through responses that do not reflect true preferences about given scenarios (García-Llorente et al., 2011). However, CV literature also 
points out that the exclusion of protest voters may result in sample selection bias (Calia \& Strazzera, 2001; Halstead et al., 1992) and impact estimates of WTP (Dziegielewska \& Mendelsohn, 2007; Haab, 1999). This is an issue to keep in mind when interpreting the results and designing future studies, where additional questions could be asked to better verify the reasons for (non)WTP that would allow for a more accurate designation of protest voter status (Blamey et al., 1999; Dziegielewska \& Mendelsohn, 2007).

In theory, some of the respondents may have had negative WTP, which is not considered in this study as per the recommendations by Hanemann (1989) and Haab and McConnell (1998). This means that the results have to be interpreted with caution, especially when making policy recommendations (Clinch \& Murphy, 2001). Around one third of the survey respondents had a preference against the expansion of the sanctuary resulting from either support for whaling or concerns over effectiveness of the proposed conservation scenario, but the study was not designed to account for the preferences of this group who may have negative WTP. This issue could be addressed in future studies by providing a wider range of bid options and additional questions or by applying different valuation methods, such as discrete choice experiments, where respondents are asked to choose between different conservation scenarios, allowing to account for a wider range of preferences (Clinch \& Murphy, 2001; Hanley et al., 2001). Also, the most recent expansion of the sanctuary to its current limit in 2017 might have affected the results of the study as respondents may not see the urgency in further expansion. The results might also have been very different if the study had occurred in the aftermath of the recent decision by the government of Iceland to continue whaling for the next five years, permitting the harvesting of 209 fin whales and 217 minke whales annually until 2023 (Vísir, 2019).

Finally, the preferences of visitors who generate the majority of income from whale watching are not taken into consideration in this study as it was concerned with the preferences of the Icelandic people. Icelanders rarely go whale watching and thus the trade-off between whale watching and whaling, although important, may not be as directly relevant to their welfare as that of the many foreign visitors who are the main 'consumers' of whale watching and, to some extent, whale meat (Bertulli et al., 2016). Even though the economic gains from both industries largely go to Icelanders, the aesthetic enjoyment and other less tangible recreational and cultural benefits enjoyed by visitors constitute an important part of whale ES values that should be considered. For this purpose, a CV study estimating the consumer surplus of the whale watching visitors in Faxaflói Bay is currently underway, aimed at accounting for preferences of foreign visitors in this regard.

Further research should also address the limitations listed above through non-monetary valuation and better estimates of non-use values of whales in Iceland; natural science research on ecological effects of different economic activities related to whale resources; and further development of non-market valuation techniques to address the problems of a high percentage of protest voters and potentially negative WTP. For improved understanding of 
trade-offs between different uses of whale resources that could inform MSP, a transdisciplinary approach is required as well as close cooperation between ES valuation practitioners, natural scientists and policy practitioners (Granek et al., 2010; Guerry et al., 2012; Jobstvogt, Watson, et al., 2014; Lester et al., 2013; Torres \& Hanley, 2017).

\section{Conclusion}

Effective marine spatial planning requires reconciliation of different and sometimes conflicting activities and resulting trade-offs. For this purpose, a transdisciplinary approach is needed combining environmental, social and economic information and transcending subject boundaries to provide policy-relevant research. Using the contingent valuation method, this study set out to elicit Icelanders' preferences and estimate willingness to pay for the expansion of the Faxaflói Bay Whale Sanctuary, which would ban commercial whaling in the entirety of the bay. In so doing, it adds new data to the international non-market valuation literature on marine spatial planning and, in particular, the whale watching versus whaling debate in Iceland. It holds a potential to inform decision-makers about the trade-offs between cultural and provisioning whale ES and public preferences regarding the management of Faxaflói Bay.

The mean willingness to pay of the 320 respondents who expressed clear preferences regarding the possible expansion, including genuine zero WTP, was 5,082 ISK (42 USD in 2018), which, when upscaled to the number of taxpayers in Iceland, amounted to 1.32 billion ISK (10,9 million USD in 2019). The study shows that younger people, women, universityeducated respondents and those who prioritise the protection of natural areas had higher WTP, whereas supporting whaling and living with more people in a household negatively affected WTP. It also reinforces the outcomes in public opinion polls that Icelanders are divided on the issue of whaling. This information is very timely, with fin and minke whaling in Iceland having been extended until 2023 and the public debate on whaling continuing locally and internationally.

However, some important questions remain regarding the effects of economic activities on the marine ecosystem of the Faxaflói Bay and its capacity to provide ES; valuing the full range of ES provided by whales, trade-offs between different ES; and management mechanisms that would address them. Further research in these areas could inform marine conservation and spatial planning in Iceland and beyond from an ES perspective, contributing to the United Nations' Sustainable Development Goal 14 on the conservation and sustainable use of oceans, seas and marine resources, and adoption of ecosystem-based management. 


\section{References:}

Aanesen, M., Armstrong, C., Czajkowski, M., Falk-Petersen, J., Hanley, N., \& Navrud, S. (2015). Willingness to pay for unfamiliar public goods: Preserving cold-water coral in Norway. Ecological economics, 112, 53-67, https://doi.org/10.1016/j.ecolecon.2015.02.007.

Ackerman, R. B. (2002). Japanese whaling in the Pacific Ocean: Defiance of international whaling norms in the name of scientific research, culture, and tradition. BC Int'l Comp. L. Rev., 25, 323.

Althingi. (2006). Veiðar í fiskveiðilandhelgi Íslands, 1. umræða. Retrieved from https://www.althingi.is/skodalid.php?lthing=133\&lidur=lid20061109T193352.

Arrow, K., Solow, R., Portney, P. R., Leamer, E. E., Radner, R., \& Schuman, H. (1993). Report of the NOAA panel on contingent valuation. Federal register, 58(10), 4601-4614.

Balmford, A., Bruner, A., Cooper, P., Costanza, R., Farber, S., Green, R. E., Madden, J. (2002). Economic reasons for conserving wild nature. Science, 297(5583), 950-953.

Barbier, E. B., Baumgärtner, S., Chopra, K., Costello, C., Duraiappah, A., Hassan, R., Polasky, S. (2009). The valuation of ecosystem services. In S. Naeem, D. Bunker, A. Hector, M. Loreau, \& C. Perrings (Eds.), Biodiversity, Ecosystem Functioning, and Human Wellbeing: An Ecological and Economic Perspective (pp. 248-262). Oxford: Oxford University Press.

Batel, A., Basta, J., \& Mackelworth, P. (2014). Valuing visitor willingness to pay for marine conservation - The case of the proposed Cres-Lošinj Marine Protected Area, Croatia. Ocean \& Coastal Management, 95, 72-80, https://doi.org/10.1016/j.ocecoaman.2014.03.025.

Bateman, I. J., Carson, R. T., Day, B., Hanemann, M., Hanley, N., Hett, T., Swanson, J. (2002). Economic valuation with stated preference techniques: a manual. Cheltenham: Edward Elgar Publishing Ltd.

Bertulli, C. G., Leeney, R. H., Barreau, T., \& Matassa, D. S. (2016). Can whale-watching and whaling co-exist? Tourist perceptions in Iceland. Journal of the Marine Biological Association of the United Kingdom, 96(4), 969-977 https://doi.org/10.1017/S002531541400006X.

Blamey, R. K., Bennett, J. W., \& Morrison, M. D. (1999). Yea-Saying in Contingent Valuation Surveys. Land Economics, 75(1), 126-141, https://doi.org/10.2307/3146997.

Blomquist, G. C., \& Whitehead, J. C. (1998). Resource quality information and validity of willingness to pay in contingent valuation. Resource and Energy Economics, 20(2), 179-196, https://doi.org/10.1016/S0928-7655(97)00035-3.

Bonnichsen, O., \& Olsen, S. B. (2016). Correcting for non-response bias in contingent valuation surveys concerning environmental non-market goods: an empirical investigation using an online panel. Journal of Environmental Planning and Management, 59(2), 245-262, https://doi.org/10.1080/09640568.2015.1008626.

Börger, T., Beaumont, N. J., Pendleton, L., Boyle, K. J., Cooper, P., Fletcher, S., Austen, M. C. (2014). Incorporating ecosystem services in marine planning: The role of valuation. Marine Policy, 46, 161-170, https://doi.org/10.1016/j.marpol.2014.01.019.

Börger, T., Hattam, C., Burdon, D., Atkins, J. P., \& Austen, M. C. (2014). Valuing conservation benefits of an offshore marine protected area. Ecological economics, 108, 229-241, https://doi.org/10.1016/j.ecolecon.2014.10.006.

Boxall, P. C., Adamowicz, W. L., Olar, M., West, G. E., \& Cantin, G. (2012). Analysis of the economic benefits associated with the recovery of threatened marine mammal species in the Canadian 
St. Lawrence Estuary. Marine Policy, 36(1), 189-197,

https://doi.org/10.1016/j.marpol.2011.05.003.

Braat, L. C., \& de Groot, R. (2012). The ecosystem services agenda:bridging the worlds of natural science and economics, conservation and development, and public and private policy. Ecosystem Services, 1(1), 4-15, https://doi.org/10.1016/j.ecoser.2012.07.011.

Brouwer, R., Brouwer, S., Eleveld, M. A., Verbraak, M., Wagtendonk, A. J., \& van der Woerd, H. J. (2016). Public willingness to pay for alternative management regimes of remote marine protected areas in the North Sea. Marine Policy, 68, 195-204, https://doi.org/10.1016/j.marpol.2016.03.001.

Brown, K., Adger, W. N., Tompkins, E., Bacon, P., Shim, D., \& Young, K. (2001). Trade-off analysis for marine protected area management. Ecological economics, 37(3), 417-434, https://doi.org/10.1016/S0921-8009(00)00293-7.

Brydon, A. (2006). The predicament of nature: Keiko the whale and the cultural politics of whaling in Iceland. Anthropological quarterly, 79(2), 225-260.

Butler, C., \& Oluoch-Kosura, W. (2006). Linking future ecosystem services and future human wellbeing. Ecology and Society, 11(1).

Calia, P., \& Strazzera, E. (2001). A sample selection model for protest votes in contingent valuation analyses. Statistica, 61, 473-485.

Carson, R. T. (1991). Constructed Markets. In J. B. Braden, \& Kolstad, C. D. (Ed.), Measuring the Demand for Environmental Quality (pp. 121-160). Amsterdam: Elsevier Science Pub. Co.

Carson, R. T. (2000). Contingent Valuation: A User's Guide. Environmental Science \& Technology, 34(8), 1413-1418, https://doi.org/10.1021/es990728j.

Carson, R. T. (2012). Contingent valuation: A practical alternative when prices aren't available. Journal of economic perspectives, 26(4), 27-42.

Carson, R. T., Flores, N. E., \& Meade, N. F. (2001). Contingent Valuation: Controversies and Evidence. Environmental and Resource Economics, 19(2), 173-210, https://doi.org/10.1023/a:1011128332243.

Carson, R. T., \& Hanemann, W. M. (2005). Chapter 17 Contingent Valuation. In K.-G. Mler \& J. R. Vincent (Eds.), Handbook of Environmental Economics (Vol. 2, pp. 821-936): Elsevier.

Carson, R. T., Mitchell, R. C., Hanemann, M., Kopp, R. J., Presser, S., \& Ruud, P. A. (2003). Contingent Valuation and Lost Passive Use: Damages from the Exxon Valdez Oil Spill. Environmental and Resource Economics, 25(3), 257-286, https://doi.org/10.1023/a:1024486702104.

Carson, R. T., Mitchell, R. C., Hanemann, W. M., Kopp, R. J., Presser, S., \& Ruud, P. A. (1992). A contingent valuation study of lost passive use values resulting from the Exxon Valdez oil spill. MPRA Paper 6984.

Casiwan-Launio, C., Shinbo, T., \& Morooka, Y. (2011). Island Villagers' Willingness to Work or Pay for Sustainability of a Marine Fishery Reserve: Case of San Miguel Island, Philippines. Coastal Management, 39(5), 459-477, https://doi.org/10.1080/08920753.2011.582573.

Chan, K. M., Satterfield, T., \& Goldstein, J. (2012). Rethinking ecosystem services to better address and navigate cultural values. Ecological economics, 74, 8-18, https://doi.org/10.1016/j.ecolecon.2011.11.011.

Clinch, J., \& Murphy, A. (2001). Modelling Winners and Losers in Contingent Valuation of Public Goods: Appropriate Welfare Measures and Econometric Analysis. The Economic Journal, 111(470), 420-443, https://doi.org/10.1111/1468-0297.00614. 
Collis, M. (2019). Whales' brighter future. New Scientist, 241(3212), 24-25, https://doi.org/10.1016/S0262-4079(19)30063-6.

Cook, D., Davíðsdóttir, B., \& Kristófersson, D. M. (2016). Energy projects in Iceland - Advancing the case for the use of economic valuation techniques to evaluate environmental impacts. Energy Policy, 94, 104-113, https://doi.org/10.1016/j.enpol.2016.03.044.

Cook, D., Davíđsdóttir, B., \& Kristófersson, D. M. (2017). An ecosystem services perspective for classifying and valuing the environmental impacts of geothermal power projects. Energy for Sustainable Development, 40, 126-138, https://doi.org/10.1016/j.esd.2017.07.007.

Cook, D., Davíđsdóttir, B., \& Kristófersson, D. M. (2018a). Willingness to pay for the preservation of geothermal areas in Iceland - The contingent valuation studies of Eldvörp and Hverahlíø. Renewable Energy, 116, 97-108, https://doi.org/10.1016/j.renene.2017.09.072.

Cook, D., Eiríksdóttir, K., Davíđsdóttir, B., \& Kristófersson, D. M. (2018b). The contingent valuation study of Heiðmörk, Iceland - Willingness to pay for its preservation. Journal of Environmental Management, 209, 126-138, https://doi.org/10.1016/j.jenvman.2017.12.045.

Cook, D., Malinauskaite, L., Davíđsdóttir, B., Ögmundardóttir, H., \& Roman, J. (2019a). Reflections on the ecosystem services of whales and how their contribution to human well-being might be valued (in review). Ocean and Coastal Management.

Cook, D., Malinauskaite, L., Roman, J., Davíđsdóttir, B., \& Ögmundardóttir, H. (2019b). Whale sanctuaries - An analysis of their contribution to marine ecosystem-based management. Ocean \& Coastal Management, 104987, https://doi.org/10.1016/j.ocecoaman.2019.104987.

Cunningham, P. A., Huijbens, E. H., \& Wearing, S. L. (2012). From whaling to whale watching: examining sustainability and cultural rhetoric. Journal of Sustainable Tourism, 20(1), 143161, https://doi.org/10.1080/09669582.2011.632091.

Daily, G. (1997). Nature's services: societal dependence on natural ecosystems. Washington, DC: Island Press.

Dempster, P. (2009). Socio-economic value of cetacean conservation. Syneca Consulting Pty Ltd. Retrieved from http://citeseerx.ist.psu.edu/viewdoc/download?doi=10.1.1.364.7296\&rep=rep1\&type=pdf.

Dillman, D. A. (2011). Mail and Internet surveys: The tailored design method--2007 Update with new Internet, visual, and mixed-mode guide. New Jersey: John Wiley \& Sons.

Directorate of Internal Revenue, R. (2016). Fjöldi framteljanda árið 2016. Retrieved from https://greining.rsk.is/Einstaklingar/1.

Dziegielewska, D. A., \& Mendelsohn, R. (2007). Does "No" mean "No"? A protest methodology. Environmental and Resource Economics, 38(1), 71-87, https://doi.org/10.1007/s10640-0069057-4.

Edwards, S. F., \& Anderson, G. D. (1987). Overlooked Biases in Contingent Valuation Surveys: Some Considerations. Land Economics, 63(2), 168-178, https://doi.org/10.2307/3146578.

Ehler, C., \& Douvere, F. (2009). Marine Spatial Planning: a step-by-step approach toward ecosystembased management. Retrieved from https://development.oceanbestpractices.net/bitstream/handle/11329/459/186559e.pdf?se quence $=1$.

Einarsdóttir, S. R., Cook, D., \& Davíđsdóttir, B. (2019). The contingent valuation study of the wind farm Búrfellslundur - Willingness to pay for preservation. Journal of Cleaner Production, 209, 795-802, https://doi.org/10.1016/j.jclepro.2018.10.156. 
Einarsson, N. (2009). From good to eat to good to watch: whale watching, adaptation and change in Icelandic fishing communities. Polar Research, 28(1), 129-138.

Estes, J. A., Demaster, D. P., Doak, D. F., Brownell, R. L., \& Williams, T. M. (2006). Whales, whaling, and ocean ecosystems. Berkeley: University of California Press.

Eurobarometer, E. (2014). Attitudes of European citizens towards the environment. Retrieved from http://ec.europa.eu/commfrontoffice/publicopinion/archives/ebs/ebs_416_sum_en.pdf.

Fiskifréttir. (2018). Hrefnuveiðum hætt. Retrieved from http://www.fiskifrettir.is/frettir/hrefnuveidum-haett/148844/.

Fleming, C. M., \& Bowden, M. (2009). Web-based surveys as an alternative to traditional mail methods. Journal of Environmental Management, 90(1), 284-292, https://doi.org/10.1016/j.jenvman.2007.09.011.

Freeman III, A. M., Herriges, J. A., \& Kling, C. L. (2014). The measurement of environmental and resource values: theory and methods. Routledge, New York.

Gallup Iceland, G. (2017). Icelanders' attitude towards whale hunting. Retrieved from https://s3.amazonaws.com/ifaw-pantheon/sites/default/files/legacy/default/IFAW-GallupOct2017-full-version.pdf.

García-Llorente, M., Martín-López, B., \& Montes, C. (2011). Exploring the motivations of protesters in contingent valuation: Insights for conservation policies. Environmental Science \& Policy, 14(1), 76-88, https://doi.org/10.1016/j.envsci.2010.11.004.

Gerber, L. R., Hyrenbach, K. D., \& Zacharias, M. A. (2005). Do the Largest Protected Areas Conserve Whales or Whalers? Science, 307(5709), 525-526, https://doi.org/10.1126/science.1106120 \%J Science.

Gillespie, A. (1996). The Ethical Question in the Whaling Debate. 9 Geo. Int'/ Envtl. L. Rev., 9, 355.

Giraud, K., Turcin, B., Loomis, J., \& Cooper, J. (2002). Economic benefit of the protection program for the Steller sea lion. Marine Policy, 26(6), 451-458, https://doi.org/10.1016/S0308597X(02)00025-8.

Gjerden, K. M. (2008). Regulatory and governance gaps in the international regime for the conservation and sustainable use of marine biodiversity in areas beyond national jurisdiction: IUCN Gland, Switzerland.

Gómez-Baggethun, E., \& Martín-López, B. (2015). Ecological economics perspectives on ecosystem services valuation Handbook of Ecological Economics. Cheltenham, UK.

Gómez-Baggethun, E., Martín-López, B., Barton, D., Braat, L., Saarikoski, H., Kelemen, E., Berry, P. (2014). State-of-the-art report on integrated valuation of ecosystem services. Retrieved from http://www.openness-project.eu/sites/default/files/Deliverable\%204\%201_IntegratedValuation-Of-Ecosystem-Services.pdf.

Government of Iceland. (2017). Reglugerð um bann við hvalveiðum á tilteknum svæðum, 1035/2017. Retrieved from https://www.stjornarradid.is/lisalib/getfile.aspx?itemid=228012d3-d51411e7-9422-005056bc530c.

Granek, E. F., Polasky, S., Kappel, C. V., Reed, D. J., Stoms, D. M., Koch, E. W., Aswani, S. (2010). Ecosystem Services as a Common Language for Coastal Ecosystem-Based Management. Conservation Biology, 24(1), 207-216, https://doi.org/10.1111/j.1523-1739.2009.01355.

Green, D., Jacowitz, K. E., Kahneman, D., \& McFadden, D. (1998). Referendum contingent valuation, anchoring, and willingness to pay for public goods. Resource and Energy Economics, 20(2), 85-116, https://doi.org/10.1016/S0928-7655(97)00031-6. 
Guerry, A. D., Ruckelshaus, M. H., Arkema, K. K., Bernhardt, J. R., Guannel, G., Kim, C.-K., Spencer, J. (2012). Modeling benefits from nature: using ecosystem services to inform coastal and marine spatial planning. International Journal of Biodiversity Science, Ecosystem Services \& Management, 8(1-2), 107-121, https://doi.org/10.1080/21513732.2011.647835.

Haab, T. C. (1999). Nonparticipation or Misspecification? The Impacts of Nonparticipation on Dichotomous Choice Contingent Valuation. Environmental and Resource Economics, 14(4), 443-461, https://doi.org/10.1023/a:1008349525868.

Haab, T. C., \& McConnell, K. E. (1997). Referendum Models and Negative Willingness to Pay: Alternative Solutions. Journal of Environmental Economics and Management, 32(2), 251270, https://doi.org/10.1006/jeem.1996.0968.

Haab, T. C., \& McConnell, K. E. (1998). Referendum Models and Economic Values: Theoretical, Intuitive, and Practical Bounds on Willingness to Pay. Land Economics, 74(2), 216-229, https://doi.org/10.2307/3147052.

Haines-Young, R., \& Potschin, M. (2018). Common International Classification of Ecosystem Services (CICES) V5. 1 and guidance on the application of the revised structure. Retrieved from https://cices.eu/content/uploads/sites/8/2018/01/Guidance-V51-01012018.pdf.

Halstead, J. M., Luloff, A. E., \& Stevens, T. H. (1992). Protest Bidders in Contingent Valuation. Northeastern Journal of Agricultural and Resource Economics, 21(2), 160-169, https://doi.org/10.1017/\$0899367X00002683.

Hanemann, M. (1984). Welfare Evaluations in Contingent Valuation Experiments with Discrete Responses. American Journal of Agricultural Economics, 66(3), 332-341, https://doi.org/10.1017/S0899367X0000268310.2307/1240800.

Hanemann, M. (1989). Welfare Evaluations in Contingent Valuation Experiments with Discrete Response Data: Reply. American Journal of Agricultural Economics, 71(4), 1057-1061, https://doi.org/10.2307/1242685.

Hanemann, M., Loomis, J., \& Kanninen, B. (1991). Statistical Efficiency of Double-Bounded Dichotomous Choice Contingent Valuation. American Journal of Agricultural Economics, 73(4), 1255-1263, https://doi.org/10.2307/1242453.

Hanley, N., Hynes, S., Patterson, D., \& Jobstvogt, N. (2015). Economic valuation of marine and coastal ecosystems: is it currently fit for purpose? Journal of Ocean and Coastal Economics, 2(1), 1-24, https://doi.org/10.15351/2373-8456.1014.

Hanley, N., Mourato, S., \& Wright, R. E. (2001). Choice Modelling Approaches: A Superior Alternative for Environmental Valuatioin? Journal of Economic Surveys, 15(3), 435-462, https://doi.org/10.1111/1467-6419.00145.

Higham, J. E. S., Bejder, L., Allen, S. J., Corkeron, P. J., \& Lusseau, D. (2016). Managing whalewatching as a non-lethal consumptive activity. Journal of Sustainable Tourism, 24(1), 73-90, https://doi.org/10.1080/09669582.2015.1062020.

Higham, J. E. S., \& Lusseau, D. (2007). Urgent Need for Empirical Research into Whaling and Whale Watching. Conservation Biology, 21(2), 554-558, https://doi.org/10.1111/j.15231739.2006.00580.

Hinch, P. R., \& De Santo, E. M. (2011). Factors to consider in evaluating the management and conservation effectiveness of a whale sanctuary to protect and conserve the North Atlantic right whale (Eubalaena glacialis). Marine Policy, 35(2), 163-180, https://doi.org/10.1016/j.marpol.2010.09.002. 
Hoagland, P., \& Meeks, A. E. (2000). The demand for whalewatching at Stellwagen Bank National Marine Sanctuary. Woods Hole Oceanographic Institution, Woods Hole, MA.

Hoyt, E. (2005). Sustainable ecotourism on Atlantic islands, with special reference to whale watching, marine protected areas and sanctuaries for cetaceans. Paper presented the Biology and environment: proceedings of the Royal Irish Academy. Retrieved from https://www.researchgate.net/profile/Erich_Hoyt/publication/237451384_Sustainable_ecot ourism_on_Atlantic_islands_with_special_reference_to_whale_watching_Marine_Protecte d_Areas_and_sanctuaries_for_cetaceans/links/541010280cf2f2b29a3e06fe.pdf.

Hoyt, E. (2012). Marine protected areas for whales dolphins and porpoises: A world handbook for cetacean habitat conservation. Routledge, New York.

Hoyt, E., \& Iñiguez, M. (2008). The state of whale watching in Latin America. Whale and Dolphin Conservation Society (WDCS). Chippenham, UK. Retrieved from: https://uk.whales.org/wpcontent/uploads/sites/6/2018/08/whale-watching-latin-america.pdf.

Hussain, S. S., Winrow-Giffin, A., Moran, D., Robinson, L. A., Fofana, A., Paramor, O. A. L., \& Frid, C. L. J. (2010). An ex ante ecological economic assessment of the benefits arising from marine protected areas designation in the UK. Ecological economics, 69(4), 828-838, https://doi.org/10.1016/j.ecolecon.2009.10.007.

Iceland Magazine. (2017). Whale sanctuary in Faxaflói bay to be expanded, new sanctuary established in North Iceland. Retrieved from https://icelandmag.is/article/whale-sanctuaryfaxafloi-bay-be-expanded-new-sanctuary-established-n-iceland.

Iceland Magazine. (2018). Minke whale hunt a near total failure, thanks to expanded whale sanctuaries. Retrieved from https://icelandmag.is/article/minke-whale-hunt-a-near-totalfailure-thanks-expanded-whale-sanctuaries.

Icelandic Tourist Board. (2019a). Hvalaskođun á Íslandi (Whale Watching in Iceland). Retrieved from https://www.maelabordferdathjonustunnar.is/is/afthreying/hvalaskodun.

Icelandic Tourist Board. (2019b). Number of Foreign Visitors. Retrieved from https://www.ferdamalastofa.is/en/recearch-and-statistics/numbers-of-foreign-visitors.

IceWhale. (2019). Number of whale watching passengers in Faxaflói Bay 2001 - 2018. Visitor number count. Unpublished.

IFAW - International Fund for Animal Welfare. (2017). Reykjavík votes whaling out of Faxaflói Bay. Retrieved from https://www.ifaw.org/united-kingdom/news/reykjav\%C3\%ADk-voteswhaling-out-faxafl\%C3\%B3i-bay.

IoES - Institute of Economics at the University of Iceland. (2019). pjóđhagsleg áhrif hvalveiðaMacroeconomic Effects of Whaling. Retrieved from http://www.ioes.hi.is/sites/hhi.hi.is/files/sjz/skyrslan-endanleg17.1.2019_0.pdf.

IWC - International Whaling Commission. (1946). International Convention for the Regulation of Whaling. International Whaling Commission, Washington. Retrieved from https://archive.iwc.int/pages/view.php?ref=3607\&k=.

Jacobs, S., Dendoncker, N., Martín-López, B., Barton, D. N., Gomez-Baggethun, E., Boeraeve, F., Washbourne, C. L. (2016). A new valuation school: Integrating diverse values of nature in resource and land use decisions. Ecosystem Services, 22, 213-220, https://doi.org/10.1016/j.ecoser.2016.11.007.

Jacobsen, J. B., \& Hanley, N. (2009). Are There Income Effects on Global Willingness to Pay for Biodiversity Conservation? Environmental and Resource Economics, 43(2), 137-160, https://doi.org/10.1007/s10640-008-9226-8. 
Jin, J., Indab, A., Nabangchang, O., Thuy, T. D., Harder, D., \& Subade, R. F. (2010). Valuing marine turtle conservation: A cross-country study in Asian cities. Ecological economics, 69(10), 20202026, https://doi.org/10.1016/j.ecolecon.2010.05.018.

Jobstvogt, N., Hanley, N., Hynes, S., Kenter, J., \& Witte, U. (2014). Twenty thousand sterling under the sea: Estimating the value of protecting deep-sea biodiversity. Ecological economics, 97, 10-19, https://doi.org/10.1016/j.ecolecon.2013.10.019.

Jobstvogt, N., Watson, V., \& Kenter, J. O. (2014). Looking below the surface: The cultural ecosystem service values of UK marine protected areas (MPAs). Ecosystem Services, 10, 97-110, https://doi.org/10.1016/j.ecoser.2014.09.006.

Johnston, R. J., Boyle, K. J., Adamowicz, W., Bennett, J., Brouwer, R., Cameron, T. A., Scarpa, R. (2017). Contemporary guidance for stated preference studies. Journal of the Association of Environmental Resource Economists, 4(2), 319-405.

Jones, N., Panagiotidou, K., Spilanis, I., Evangelinos, K. I., \& Dimitrakopoulos, P. G. (2011). Visitors' perceptions on the management of an important nesting site for loggerhead sea turtle (Caretta caretta L.): The case of Rethymno coastal area in Greece. Ocean \& Coastal Management, 54(8), 577-584, https://doi.org/10.1016/j.ocecoaman.2011.05.001.

Jorgensen, B. S., Syme, G. J., Bishop, B. J., \& Nancarrow, B. E. (1999). Protest Responses in Contingent Valuation. Environmental and Resource Economics, 14(1), 131-150, https://doi.org/10.1023/a:1008372522243.

Kalland, A. (1994). Whose whale is that? Diverting the commodity path. Elephants and Whales: Resources for whom, 159-186. The Third Biennial Conference of the International Association for the Study of Common Property, Washington, DC. Retrieved from: http://dlc.dlib.indiana.edu/dlc/bitstream/handle/10535/2240/Whose_Whale_is_That_Diver ting_the_Commodity_Path.pdf?sequence $=1 \&$ isAllowed=y.

Kanninen, B. J., \& Khawaja, M. S. (1995). Measuring Goodness of Fit for the Double-Bounded Logit Model. American Journal of Agricultural Economics, 77(4), 885-890, https://doi.org/10.2307/1243811.

Karlsdóttir, U. B. (2013). Nature worth seeing! The tourist gaze as a factor in shaping views on nature in Iceland. Tourist Studies, 13(2), 139-155, https://doi.org/10.1177/1468797613490372.

Kato, K. (2007). Prayers for the Whales: Spirituality and Ethics of a Former Whaling CommunityIntangible Cultural Heritage for Sustainability. International Journal of Cultural Property, 14(3), 283-313.

Kenter, J. O., Bryce, R., Davies, A., Jobstvogt, N., Watson, V., Ranger, S., . . Crump, H. (2013). The value of potential marine protected areas in the UK to divers and sea anglers. Retrieved from https://www.researchgate.net/profile/Jasper_Kenter/publication/259265454_The_value_of _potential_marine_protected_areas_in_the_UK_to_divers_and_sea_anglers_UK_National_ Ecosystem_Assessment_interim_report/links/0a85e530c75dc6e25d000000/The-value-ofpotential-marine-protected-areas-in-the-UK-to-divers-and-sea-anglers-UK-NationalEcosystem-Assessment-interim-report.pdf.

Kjarninn. (2015). Hvalur hf. tapađi milljarđi á hvalveiðum en hagnađist um prjá milljarða króna (Hvalur Ltd. lost billions on whaling but gained about three billion Icelandic kronas). Retrieved from https://kjarninn.is/frettir/hvalur-hf-tapadi-milljardi-a-hvalveidum-enhagnadist-um-thrja-milljarda-krona/.

Kriström, B. (1997). Spike Models in Contingent Valuation. American Journal of Agricultural Economics, 79(3), 1013-1023, https://doi.org/10.2307/1244440. 
Kwak, S.-Y., Yoo, S.-H., \& Kim, C. S. (2013). Measuring the Willingness to Pay for Tap Water Quality Improvements: Results of a Contingent Valuation Survey in Pusan. Water, 5(4), 1638-1652, https://doi.org/10.3390/w5041638.

Langford, I. H., Skourtos, M. S., Kontogianni, A., Day, R. J., Georgiou, S., \& Bateman, I. J. (2001). Use and nonuse values for conserving endangered species: The case of the Mediterranean monk seal. Environment and Planning A, 33(12), 2219-2233, https://doi.org/10.1068/a348.

Lester, S. E., Costello, C., Halpern, B. S., Gaines, S. D., White, C., \& Barth, J. A. (2013). Evaluating tradeoffs among ecosystem services to inform marine spatial planning. Marine Policy, 38 , 80-89, https://doi.org/10.1016/j.marpol.2012.05.022.

Lillebø, A. I., Pita, C., Garcia Rodrigues, J., Ramos, S., \& Villasante, S. (2017). How can marine ecosystem services support the Blue Growth agenda? Marine Policy, 81, 132-142, https://doi.org/10.1016/j.marpol.2017.03.008.

Lim, S.-Y., Kim, H.-J., \& Yoo, S.-H. (2017). Public's willingness to pay a premium for bioethanol in Korea: A contingent valuation study. Energy Policy, 101, 20-27, https://doi.org/10.1016/j.enpol.2016.11.010.

Lindhjem, H., \& Navrud, S. (2011). Are Internet surveys an alternative to face-to-face interviews in contingent valuation? Ecological economics, 70(9), 1628-1637, https://doi.org/10.1016/j.ecolecon.2011.04.002.

Liu, J., Liu, N., Zhang, Y., Qu, Z., \& Yu, J. (2019). Evaluation of the non-use value of beach tourism resources: A case study of Qingdao coastal scenic area, China. Ocean \& Coastal Management, 168, 63-71, https://doi.org/10.1016/j.ocecoaman.2018.10.030.

Lusseau, D. (2008). Slaughtering the Goose that Lays the Golden Egg: Are Whaling and WhaleWatching Mutually Exclusive? AU - Higham, James E.S. Current Issues in Tourism, 11(1), 6374, https://doi.org/10.2167/cit335.0.

Lusseau, D., \& Bejder, L. (2007). The long-term consequences of short-term responses to disturbance: Experiences from whalewatching impact assessment. International Journal of Comparative Psychology, 20, 228-236. Retrieved from https://escholarship.org/uc/item/42m224qc.

Mamat, M. P., Yacob, M. R., Radam, A., Ghani, A. N. A., \& Fui, L. H. (2013). Willingness to pay for protecting natural environments in Pulau Redang Marine Park, Malaysia. African Journal of Business Management, 7(25), 2420-2426. Retrieved from http://internationalscholarsjournals.org/download.php?id=279412533315100118.pdf\&type $=$ application/pdf\&op=1.

Marta-Pedroso, C., Freitas, H., \& Domingos, T. (2007). Testing for the survey mode effect on contingent valuation data quality: A case study of web based versus in-person interviews. Ecological economics, 62(3), 388-398, https://doi.org/10.1016/j.ecolecon.2007.02.005.

Martinez-Alier, J., Kallis, G., Veuthey, S., Walter, M., \& Temper, L. (2010). Social Metabolism, Ecological Distribution Conflicts, and Valuation Languages. Ecological economics, 70(2), 153158, https://doi.org/10.1016/j.ecolecon.2010.09.024.

Mattes, S. (2017). Save the Whale? Ecological Memory and the Human-Whale Bond in Japan's Small Coastal Villages. In I. Werkheiser \& Z. Piso (Eds.), Food Justice in US and Global Contexts: Bringing Theory and Practice Together (pp. 67-81). Springer International Publishing, Cham. Mitchell, R. C., \& Carson, R. T. (2013). Using surveys to value public goods: the contingent valuation method. Resources for the Future Press, New York. 
MMR - Market and Media Research Iceland. (2018). Skiptar skoðanir um áframhaldandi hvalveiðar (Divided opinions on continuing whaling). Retrieved from https://mmr.is/frettir/birtarnieurstoeeur/686-skiptar-skodhanir-um-aframhaldandi-hvalveidhar.

Morrison, M. D., Blamey, R. K., Bennett, J. W. J. E., \& Economics, R. (2000). Minimising Payment Vehicle Bias in Contingent Valuation Studies. 16(4), 407-422, https://doi.org/10.1023/a:1008368611972.

Nahuelhual-Muñoz, L., Loureiro, M., Loomis, J. J. E., \& Economics, R. (2004). Addressing Heterogeneous Preferences Using Parametric Extended Spike Models. 27(3), 297-311, https://doi.org/10.1023/B:EARE.0000017655.38664.ce.

NAMMCO - North Atlantic Marine Mammal Commission. (2017). Nuuk Agreement. Retrieved from https://nammco.no/wp-content/uploads/2016/10/nammco-agreement-with-signaturesand-logo.pdf.

Navrud, S., Lindhjem, H., \& Magnussen, K. (2017). Valuing Marine Ecosystem Services Loss from Oil Spills for Use in Cost-Benefit Analysis of Preventive Measures. Handbook on the Economics and Management of Sustainable Oceans, 124-137.

O'Connor, S., Campbell, R., Cortez, H., \& Knowles, T. (2009). Whale Watching Worldwide: tourism numbers, expenditures and expanding economic benefits, a special report from the International Fund for Animal Welfare. Yarmouth MA, USA, prepared by Economists at Large, 228.

Parsons, E. C. M., Warburton, C. A., Woods-Ballard, A., Hughes, A., \& Johnston, P. (2003). The value of conserving whales: the impacts of cetacean-related tourism on the economy of rural West Scotland. Aquatic Conservation: Marine and Freshwater Ecosystems, 13(5), 397-415, https://doi.org/10.1002/aqc.582.

Pascual, U., Muradian, R., Brander, L., Gómez-Baggethun, E., Martín-López, B., Verma, M., ... \& Farley, J. (2010). The economics of valuing ecosystem services and biodiversity. The economics of ecosystems and biodiversity: ecological and economic foundations, 183-256. Retrieved from https://www.researchgate.net/profile/Unai_Pascual/publication/303444184_The_Economic s_of_Valuing_Ecosystem_Services_and_Biodiversity/links/5746b08208aea45ee8561db8/Th e-Economics-of-Valuing-Ecosystem-Services-and-Biodiversity.pdf.

Pearce, D., \& Moran, D. (2013). The economic value of biodiversity. Routledge, New York.

Rankin, J., \& Robinson, A. (2018). Accounting for protest zeros in contingent valuation studies: A review of literature. (No. 18-01). HEG Working Paper. Retrieved from https://www.econstor.eu/bitstream/10419/197777/1/1027441459.pdf.

Rasmussen, M. (2014). The whaling versus whale-watching debate. In: Sustainable Tourism and Management, (81-94). Cambridge University Press, Cambridge.

Ressurreição, A., Gibbons, J., Dentinho, T. P., Kaiser, M., Santos, R. S., \& Edwards-Jones, G. (2011). Economic valuation of species loss in the open sea. Ecological economics, 70(4), 729-739, https://doi.org/10.1016/j.ecolecon.2010.11.009.

Ressurreição, A., Gibbons, J., Kaiser, M., Dentinho, T. P., Zarzycki, T., Bentley, C., . . . Edwards-Jones, G. (2012). Different cultures, different values: The role of cultural variation in public's WTP for marine species conservation. Biological Conservation, 145(1), 148-159, https://doi.org/10.1016/j.biocon.2011.10.026. 
Ritter, F. (2003). Interactions of cetaceans with whale watching boats-implications for the management of whale watching tourism. Retrieved from https://m-e-er.de/download/wissenschaftliche_publikationen/Executive_Summary_Report.pdf.

Rivera, M., Muñoz, C., \& Ruiz, V. (2007). Economic valuation of whale watching in México. INE, Mexico, working paper.

Robles-Zavala, E., \& Chang Reynoso, A. G. (2018). The recreational value of coral reefs in the Mexican Pacific. Ocean \& Coastal Management, 157, 1-8, https://doi.org/10.1016/j.ocecoaman.2018.02.010

Rodella, I., Madau, F., Mazzanti, M., Corbau, C., Carboni, D., Utizi, K., \& Simeoni, U. (2019). Willingness to pay for management and preservation of natural, semi-urban and urban beaches in Italy. Ocean \& Coastal Management, 172, 93-104, https://doi.org/10.1016/j.ocecoaman.2019.01.022.

Roman, J., Estes, J. A., Morissette, L., Smith, C., Costa, D., McCarthy, J., .. S Smetacek, V. (2014). Whales as marine ecosystem engineers. Frontiers in Ecology and the Environment, 12(7), 377-385, https://doi.org/10.1890/130220.

Russi, D., Pantzar, M., Kettunen, M., Gitti, G., Mutafoglu, K., Kotulak, M., \& ten Brink, P. (2016). Socio-economic benefits of the EU marine protected areas. Institute for European Environmental Policy: London, UK.

Sæpórsdóttir, A. D., Hall, C. M., \& Saarinen, J. (2011). Making wilderness: tourism and the history of the wilderness idea in Iceland. Polar Geography, 34(4), 249-273, https://doi.org/10.1080/1088937X.2011.643928.

Sæpórsdóttir, A. D., Ólafsdóttir, R., \& Smith, D. (2018). Turbulent times: tourists' attitudes towards wind turbines in the Southern Highlands in Iceland. International Journal of Sustainable Energy, 37(9), 886-901, https://doi.org/10.1080/14786451.2017.1388236.

Samuelson, P. A. (1954). The Pure Theory of Public Expenditure. The Review of Economics and Statistics, 36(4), 387-389, https://doi.org/10.2307/1925895.

Scarff, J. (1980). Ethical issues in whale and small cetacean management. Environmental Ethics, 2(3), 241-279, https://doi.org/10.5840/enviroethics19802339.

Schläpfer, F. (2008). Contingent valuation: A new perspective. Ecological economics, 64(4), 729-740, https://doi.org/10.1016/j.ecolecon.2007.10.010.

Shen, Z., Wakita, K., Oishi, T., Yagi, N., Kurokura, H., Blasiak, R., \& Furuya, K. (2015). Willingness to pay for ecosystem services of open oceans by choice-based conjoint analysis: A case study of Japanese residents. Ocean \& Coastal Management, 103, 1-8, https://doi.org/10.1016/j.ocecoaman.2014.10.016.

Solomon, B. D., Corey-Luse, C. M., \& Halvorsen, K. E. (2004). The Florida manatee and eco-tourism: toward a safe minimum standard. Ecological economics, 50(1), 101-115, https://doi.org/10.1016/j.ecolecon.2004.03.025.

Stålhammar, S., \& Pedersen, E. (2017). Recreational cultural ecosystem services: How do people describe the value? Ecosystem Services, 26, 1-9, https://doi.org/10.1016/j.ecoser.2017.05.010.

Statistics Iceland (2017). Iceland in figures 2017. Retrieved from https://www.statice.is/media/50481/icelandinfigures2017.pdf.

Statistics Iceland (2018). Population - key figures 1703-2018. Retrieved from https://px.hagstofa.is/pxen/pxweb/en/lbuar/Ibuar_mannfjoldi_1_yfirlit_yfirlit_mannfjol da/MAN00000.px/table/tableViewLayout1/?rxid=cbbadc0c-3e0e-40bb-b950-2b38ae989bac. 
Stithou, M., \& Scarpa, R. (2012). Collective versus voluntary payment in contingent valuation for the conservation of marine biodiversity: An exploratory study from Zakynthos, Greece. Ocean \& Coastal Management, 56, 1-9, https://doi.org/10.1016/j.ocecoaman.2011.10.005.

Tallis, H., \& Polasky, S. (2009). Mapping and valuing ecosystem services as an approach for conservation and natural-resource management. Annals of the New York Academy of Sciences, 1162(1), 265-283. https://doi.org/10.1111/j.1749-6632.2009.04152.x.

The Guardian. (2018). Iceland sets target of 191 kills as country resumes whaling. Retrieved from https://www.theguardian.com/environment/2018/apr/18/iceland-sets-target-of-191-killsas-country-resumes-whaling.

The Seattle Times. (2018). Iceland company to resume commercial hunting of fin whales. Retrieved from https://www.seattletimes.com/business/iceland-company-to-resume-commercialhunting-of-fin-whales/.

Tonin, S. (2018). Citizens' perspectives on marine protected areas as a governance strategy to effectively preserve marine ecosystem services and biodiversity. Ecosystem Services, 34, 189-200, https://doi.org/10.1016/j.ecoser.2018.03.023.

Torres, C., \& Hanley, N. (2017). Communicating research on the economic valuation of coastal and marine ecosystem services. Marine Policy, 75, 99-107, https://doi.org/10.1016/j.marpol.2016.10.017.

UNESCO. (2019). Balancing sustainable use and conservation through Marine Spatial Planning. Retrieved from http://msp.ioc-unesco.org/.

Veronesi, M., Alberini, A., Cooper, J. C. J. E., \& Economics, R. (2011). Implications of bid design and willingness-to-pay distribution for starting point bias in double-bounded dichotomous choice contingent valuation surveys. 49(2), 199-215. https://doi.org/10.1007/s10640-010-9430-1.

Víkingsson, G. (2019). Minnisblað um hvalveiðar (Memorandum on whaling). Retrieved from https://www.stjornarradid.is/lisalib/getfile.aspx?itemid=e313af02-339e-11e9-9432005056bc530c.

Vísir. (2017). Porgerður Katrín stækkar friðunarsvæđi hvala á síđustu dögum starfsstjórnarinnar (Environment Minister expands the whale conservation area in the last days of the administration). Retrieved from http://www.visir.is/g/2017171128782/thorgerdur-katrinstaekkar-fridunarsvaedi-hvala-a-sidustu-dogum-starfsstjornarinnar.

Vísir. (2019). Ný reglugerð heimilar áframhaldandi veiđar á langreyđi og hrefnu til ársins 2023. Retrieved from http://www.visir.is/g/2019190218711/ny-reglugerd-heimilar-aframhaldandiveidar-a-langreydi-og-hrefnu-til-arsins-2023

Wallmo, K., \& Lew, D. K. (2016). A comparison of regional and national values for recovering threatened and endangered marine species in the United States. Journal of Environmental Management, 179, 38-46, https://doi.org/10.1016/j.jenvman.2016.04.053.

Wang, P.-W., \& Jia, J.-B. (2012). Tourists' willingness to pay for biodiversity conservation and environment protection, Dalai Lake protected area: Implications for entrance fee and sustainable management. Ocean \& Coastal Management, 62, 24-33, https://doi.org/10.1016/j.ocecoaman.2012.03.001.

Wattage, P., Glenn, H., Mardle, S., Van Rensburg, T., Grehan, A., \& Foley, N. (2011). Economic value of conserving deep-sea corals in Irish waters: A choice experiment study on marine protected areas. Fisheries Research, 107(1), 59-67, https://doi.org/10.1016/j.fishres.2010.10.007. 
White, C., Halpern, B. S., \& Kappel, C. V. (2012). Ecosystem service tradeoff analysis reveals the value of marine spatial planning for multiple ocean uses. Proceedings of the National Academy of Sciences, https://doi.org/10.1073/pnas.1114215109.

Whitehead, J. C., Groothuis, P. A., \& Blomquist, G. C. (1993). Testing for non-response and sample selection bias in contingent valuation: Analysis of a combination phone/mail survey. Economics Letters, 41(2), 215-220, https://doi.org/10.1016/0165-1765(93)90200-V.

Williams, N. (2006). Iceland shunned over whale hunting. Current Biology, 16(23), R975-R976, https://doi.org/10.1016/j.cub.2006.11.006.

Yoo, S. H., \& Kwak, S. J. (2002). Using a spike model to deal with zero response data from double bounded dichotomous choice contingent valuation surveys. Applied Economics Letters, 9(14), 929-932, https://doi.org/10.1080/13504850210139378.

Zacharias, M. A., Gerber, L. R., \& Hyrenbach, K. D. (2006). Review of the Southern Ocean Sanctuary: marine protected areas in the context of the International Whaling Commission Sanctuary Programme. Journal of Cetacean Research and Management, 8(1), 1. 